\title{
Multiregional Emergence of Mobile Pastoralism and Nonuniform Institutional Complexity across Eurasia
}

\author{
by Michael D. Frachetti
}

\begin{abstract}
In this article I present a new archaeological synthesis concerning the earliest formation of mobile pastoralist economies across central Eurasia. I argue that Eurasian steppe pastoralism developed along distinct local trajectories in the western, central, and (south)eastern steppe, sparking the development of regional networks of interaction in the late fourth and third millennia BC. The "Inner Asian Mountain Corridor" exemplifies the relationship between such incipient regional networks and the process of economic change in the eastern steppe territory. The diverse regional innovations, technologies, and ideologies evident across Eurasia in the mid-third millennium BC are cast as the building blocks of a unique political economy shaped by "nonuniform" institutional alignments among steppe populations throughout the second millennium BC. This theoretical model illustrates how regional channels of interaction between distinct societies positioned Eurasian mobile pastoralists as key players in wide-scale institutional developments among traditionally conceived "core" civilizations while also enabling them to remain strategically independent and small-scale in terms of their own sociopolitical organization. The development of nonuniform institutional complexity among Eurasian pastoralists demonstrates a unique political and economic structure applicable to societies whose variable political and territorial scales are inconsistent with commonly understood evolutionary or corporate sociopolitical typologies such as chiefdoms, states, or empires.
\end{abstract}

\section{Introduction}

\section{The Eurasian Pastoralist Revolution?}

Mobile pastoralists have defined pervasive systems of ecological and political adaptation that have irrevocably shaped the nature of economic and social interaction across western and central Asia for more than 5,000 years (Hole 1987; LambergKarlovsky 1974; Masson 2006; Shaffer 1978; Tosi 1972). Ethnohistorical studies document how prevalent modes of specialized pastoralism across the central-Eurasian steppes exhibit diverse practices of mobility and herd structure; they also highlight how diffuse political organization of steppe pastoralists both promoted and antagonized the growth of empires and states throughout antiquity (Di Cosmo 1994, 2003; Lattimore 1940; Rogers 2007). Recent archaeological

Michael D. Frachetti is Associate Professor in the Department of Anthropology at Washington University in St. Louis (Campus Box 1114, One Brookings Drive, St. Louis, Missouri 63130-4899, U.S.A. [frachetti@wustl.edu]). This paper was submitted 30 XII 09 and accepted 6 XII 10. research on Eurasian pastoralists is casting new light on their catalytic roles in the development and organization of prehistoric civilizations across Eurasia and thus prompts a shift in focus from large-scale sedentary agricultural societies toward mobile pastoralists as key players in the growth of complex systems of economic and political interaction from China to the Black Sea, Mesopotamia, and the Indus Valley (Alizadeh 2010; Anthony 2007; Frachetti 2008; Possehl 2004).

Collaborative research over the past decade in particular has recast our view of steppe societies from inert "cultural communities" to agents in evolving systems of exchange and technological innovation reaching far beyond the steppe boundaries (Boyle, Renfrew, and Levine 2002; Hanks and Linduff 2009; Levine, Renfrew, and Boyle 2003; Peterson, Popova, and Smith 2006; Popova, Hartley, and Smith 2007). Ongoing projects increasingly extend the prehistoric time depth of Eurasian pastoralist landscapes and resituate the regional and chronological range of material and technological developments that shaped early steppe societies (Anthony et al. 2005; Chang et al. 2003; Frachetti and Mar'yashev 2007; Hanks, Epimakhov, and Renfrew 2007; Olsen et al. 2006; Parzinger and Boroffka 2003; Wright, Honeychurch, and Amartuvshin 2009). Taken synthetically, new data position central Eurasia 
as the host of key innovations, such as horse domestication and chariots, and as the terrain for distant transmission of commodities such as semiprecious stones, domesticated grains, and bronze technology and the ideological and political institutions associated with these innovations (Frachetti et al. 2010; Mei 2003; Outram et al. 2009). This outburst of discoveries in central Eurasia elicits the questions (1) How did materials and ideas innovated in the steppe diffuse or translate beyond the steppe region and (2) How were they integrated into larger-scale centralized societies in south, southwest, and east Asia? To understand the wider political economy of Eurasia before the historical era, we might concentrate our attention on the importance of steppe pastoralists in shaping the institutional landscapes that bridged traditionally conceived "core" regions of civilization (Anthony 2007).

In the Near East and east Asia, nomadic societies have commonly been cast as disruptive forces to the success of "civilizations," be they the Amorites de-structuring the Ur III city-state (Postgate 1992:42) or the Xiongnu marauding on the western frontiers of the Chinese state (Lattimore 1940). Such portrayals are derived primarily from written sources, which not surprisingly record the etic perspectives of chroniclers rather than the emic narratives of the respective "nomads." To productively insert mobile pastoralist political economies into the broader historical story line of world civilizations, we must start by understanding mobile pastoralist strategies and interactive arenas in their own right.

This is no easy task, because Eurasian steppe archaeology is both patchy and deeply rooted in an academic tradition that situates the steppe zone as peripheral to the main currents of social complexity (Hanks 2010). Admittedly, the archaeology discussed in this paper does not escape the pervasive problems of historically and methodologically inconsistent collection methods, imperfect or incomplete data, and limited reporting and publication of key materials. However, the scientific integration of absolute dating and modern archaeological methods is reforming long-standing explanatory paradigms of the region's prehistory (Kradin 2008; Rassamakin 2002; Shishlina 2008). In fact, apparent contradictions between new data and standing theories are sparking further revisions to Eurasian prehistory (Honeychurch and Amartuvshin 2007; Peterson 2007; Salvatori 2008; Stride, Rondelli, and Mantellini 2009).

With central Eurasia at the physical "center" of our conceptual map, east Asia, south Asia, Mesopotamia, and the Black Sea/Anatolia align along its borders (fig. 1). This perspective geographically illustrates how central-Eurasian communities were situated at the social crossroads of these regions. The inherent danger with such a mapping is that it risks conflating the diversity of steppe communities into a monolithic unit or "academic other." A conglomerate view of "steppe societies" has been the norm in archaeology to date-especially concerning Eurasian pastoralists. With new research it is now possible to carve the central-Eurasian mac- roregion into more refined territories and to examine in greater detail the chronology and distribution of unique developments of specialized mobile pastoralism throughout prehistory (fig. 2). Exposing the regional conditions that spurred the evolution of specialized pastoralism in these subregions also grounds the rich matrix of material and shared ideologies that ultimately drew steppe communities into a wider realm of contact and cultural exchange in the late Bronze Age (Kotova 2008; Lamberg-Karlovsky 2002). Although the evolution of mobile pastoralism on the steppe is only beginning to be linked archaeologically to the growth of interregional exchange networks among societies beyond the steppe region, it is fundamental to any discussion of prehistoric political economies of Eurasia (Kohl 2008).

\section{Overview of Arguments}

The predominant model of development of Eurasian steppe pastoralism (and its associated innovations) proposes that specialized herding economies were derived from agricultural societies living in the western regions of Eurasia, north of the Black Sea, around the end of the fifth or early fourth millennium BC (Gimbutas 1965; Koryakova and Epimakhov 2007; Shnirel'man 1992). Throughout the fourth and third millennia BC, mobile pastoralists became increasingly reliant on domesticated cattle, sheep, and horses (along with riding and wagons) and systematically expanded eastward across the steppe in response to environmental change and the demand for increased pasture (Anthony 2007; Kotova 2008:121-123; Kuz'mina 1994; Merpert 1974). According to traditional models, by the late Bronze Age (ca. 1900-1300 BC) mobile herding communities had come to occupy the entire Eurasian steppe and had begun to migrate into territories beyond the steppe such as southern central Asia (Kuz'mina 2008; Vinogradova 1993). Their characteristic forms of metallurgy, ceramics, and Indo-European language and ideology are thought to form a geographically broad and culturally (or materially) interrelated group of societies academically known under the moniker "Andronovo cultural community" (Anthony 1998; Kuz'mina 1986, 2007; Mallory 1989). Consequently, the vast "cultural community" defined by regional herding communities formed an "ethnogenetic" stage for the evolution of statelike mounted nomadic societies such as the Scythians, the Saka, and the Xiongnu during the first millennium BC (Akishev and Kushaev 1963). Variations of this overarching paradigm remain current and are reflected in more detailed scholarship by archaeologists, historians, human biologists, and linguists (Anthony 2007; Di Cosmo 2003; Hemphill and Mallory 2004; Wells et al. 2001).

Some aspects of the traditional model have good archaeological correlates in a few discrete territories across Eurasia (Anthony et al. 2005; Chernykh et al. 2002). However, if we dismantle the view of the steppe as a cultural/territorial unit, then the proposal of staged migrations to explain the distribution of regional material assemblages appears to oversim- 


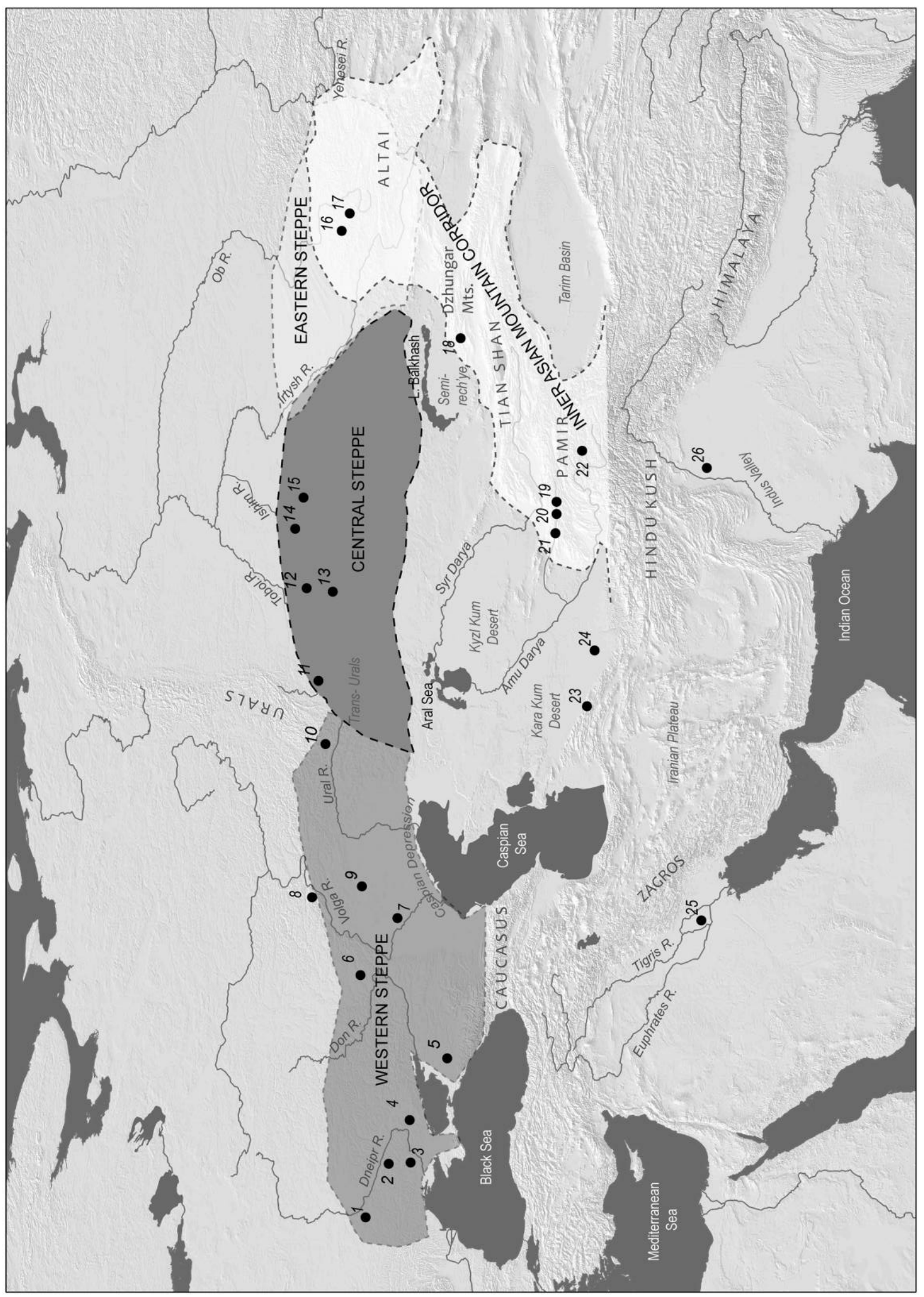

This content downloaded from 129.237.046.008 on July 18, 2016 08:54:26 AM 
plify the local histories and ecological particulars that shaped the development of early steppe herders in specific locales. The traditional diffusion model also obscures the local institutional pressures that sparked innovations among societies in the western, central, and eastern regions of the steppe and elsewhere.

Comparing the basis of the economy and the ecological strategy in each region, I suggest here that the earliest forms of herding are not well explained by the traditional linear model of diffusion from a single center of domestication (Harlan 1971), while long-held truths, such as the relationship between horse domestication and the rise of mobile pastoralism on the steppe, are shown to be regionally conscribed rather than inherent macroregional realities. Instead, I argue that mobile pastoralism emerged differently in the western, central, and eastern regions of the Eurasian steppe zone and took various specialized forms in the fourth and early third millennia BC. Although not entirely autochthonous, pastoralist strategies in each of these regions matured in light of unique ecological factors and local social interactions. Newly emerging evidence also helps to illustrate a new vector of economic transition along the Inner Asian Mountain Corridor (IAMC) proposed here to explain the growth of pastoralist economies in the (south)eastern regions of the Eurasian steppe (fig. 1).

The thesis presented here also opens intellectual territory for new conceptual models that may better describe how largely distinct socioeconomic communities-gestating in the fourth and third millennia $\mathrm{BC}$ - contributed to the subsequent interregional alignments of social institutions across and beyond the steppe by the second millennium BC (Hanks and Linduff 2009). Because early Bronze Age steppe societies were not centrally organized or confederated, local institutional parameters likely structured their economic and political organizations (Frachetti 2009). As specialized groups interacted with their regional neighbors, "nonuniform" institutional relationships formed and drew local societies into widening arenas of interactionwhat Kohl (2008) terms "social fields"- that crossed material, ideological, and ecological boundaries.

Here, institutions are defined as the organizational and ideological norms that shape practical interactions of agents and communities (North 1990). Broadly conceived, institutions may include religious rites for burial or social and political structures that define the "rules of engagement" for trade and alliances (kinship, age sets, bureaucracy). Institu- tions may also reflect standards of social status or informal rights to particular commodities or resources, such as usufruct (Barth 1961). In the steppe context, institutional "nonuniformity" describes a condition wherein some institutional categories spread along channels of interaction beyond local communities to resonate at wider geographic scales among diverse societies while other institutions remained local and specific. For example, institutionally employed associations between restricted commodities and high social status appear to have structured practices across Eurasia such as interring horses or offering domesticated grains during burial rituals. Although initially a regional phenomenon, the use of domesticates as burial offerings in institutionally (or structurally) similar ways is documented widely across the steppe among a variety of societies by the mid-second millennium BC (Outram et al. 2011).

Other institutions, such as the political organizations of regional communities, appear to have retained localized diversity across Eurasia well into the late Bronze Age (Epimakhov 2009b). Beyond such examples, the full complement of institutions that shaped a given community might reflect a range of alignments that span highly diverse geographic scales, depending on the extensiveness and formality of social interactions among groups. I have argued elsewhere that regional interactive networks were generated in the regular course of communication among neighboring pastoralists (Frachetti 2008). As these networks formed, the passage of key innovations and their associated institutional significance slowly fostered particular practices and norms to resonate more widely across the steppe and in some cases to diffuse to political economies beyond the steppe periphery.

Well-documented material transfers between steppe pastoralists and urban agriculturalists in southern central Asia, the Indus Valley, China, the Iranian Plateau, and perhaps as far as Mesopotamia indicate that populations from inner Asia helped shape the channels of trade and resource acquisition for a variety of civilizations in the late Bronze Age and thus influenced the evolution of these respective political landscapes (Alizadeh 2010; Kenoyer 2004; Lamberg-Karlovsky 2009; Possehl 2002; Potts 1999; Salvatori 2008). Others scholars have published detailed treatments of the production and regional distribution of many of these innovations and materials (Chernykh 2009; Lamberg-Karlovsky and Tosi 1973; Law 2006). Below, I briefly highlight the regional expansion of wheeled vehicles and bronze metallurgy to exemplify how

Figure 1. Geography of the western, central, and eastern Eurasian steppe zones, the Inner Asian Mountain Corridor, and the primary sites mentioned in the text. 1, Moliukhor Bugor; 2, Derievka; 3, Mikhailovka; 4, Sredny Stog; 5, Maikop; 6, Repin; 7, Kyzl-khak II; 8, Kvalynsk; 9, Kara Khuduk I; 10, Kargaly; 11, Sintashta; 12, Duzbai 3; 13, Solenoe Ozero I; 14, Botai; 15, Krasnyi Yar; 16, Kara-Tenesh; 17, Balyktyul; 18, Begash; 19, Dashti Kozy; 20, Zarcha-khalifa; 21, Sarazm; 22, Kangurt-tut; 23, Anau; 24, Gonur; 25, Uruk; 26, Harappa. A color version of this figure is available in the online edition of Current Anthropology. 


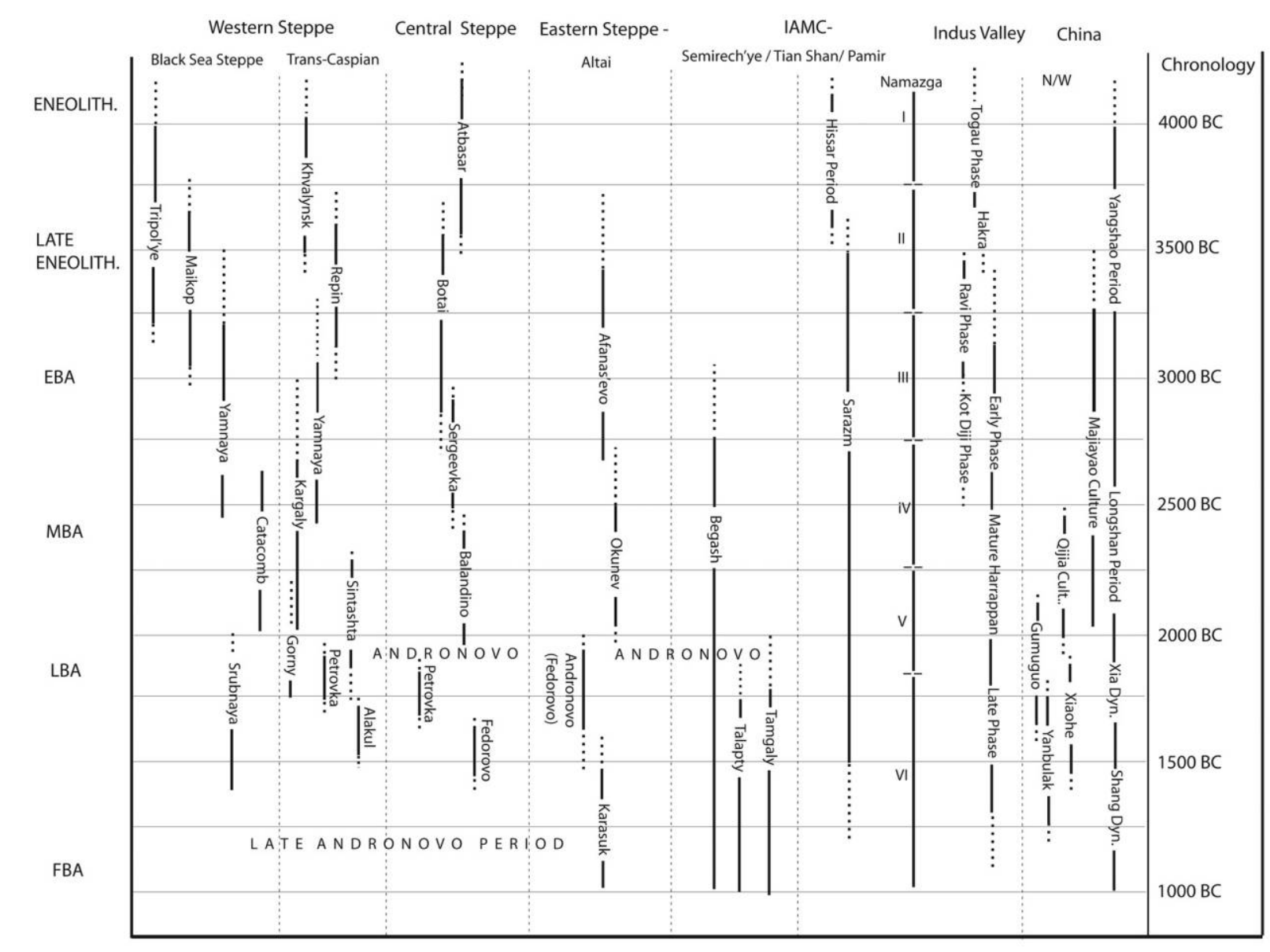

Figure 2. Comparative regional chronologies of main archaeological assemblages and sites discussed in the text. IAMC, Inner Asian Mountain Corridor; EBA, early Bronze Age; MBA, middle Bronze Age; LBA, late Bronze Age; FBA, final Bronze Age.

their institutional deployment as prestige items fostered the growth of "nonuniform" political structures across Eurasia.

The theoretical aim of this paper is to trace the process by which local steppe populations transformed their regionally diverse economies into an integrated network of interaction with aspects of broad institutional resonance as well as local diversity. The paradigm presented here provides a perspective different from those that tie expanding networks of interaction and shared institutional policies to formal political hierarchies (the state) or corporate political bodies (chiefdoms; Pauketat 2007). I propose that an array of nonuniformly aligned institutional structures better explains the dynamic social structure of steppe communities and that the channels of interaction that shape them engendered a wide distribution of technologies, material cultural, and ideology across central Eurasia. This nonuniform institutional structure across central Eurasia ultimately linked societies from China to the Near East and Europe by the late second millennium BC.

\section{Transitions to Mobile Pastoralism in Three Regions of Eurasia (5000-2500 BC)}

\section{Mobile Pastoralism as a Specialized System}

Ethnographically, mobile pastoralism describes an economic and social strategy where communities provide for their needs primarily through the intensive management of domestic herds and rely on patterned (seasonal) migrations to support the health, socioeconomic prosperity, and political success of their population (Salzman 2002). Cross-culturally, mobile pastoralists exhibit a wide range of strategies, and there is considerable variation in their annual mobility and supplementary resource exploitation (agriculture, trade, mining, craft production), depending on both ecological and sociopolitical pressures (Beck 1991; Bernbeck 2008). Although gen- 
erally distinguishable from settled farming, mobile pastoralist socioeconomic systems sometimes overlap with small-scale animal keeping or localized ranching among sectors of agricultural communities. Here, I demarcate mobile pastoralism as animal keeping more intensive and specialized than tethered agropastoralism, even though the origins of these adaptations are sometimes, but not necessarily, interrelated (Shnirel'man 1992). For example, across most of the Near East and Europe, animal herding emerged as part of a mixed agricultural strategy in the Neolithic (8500-4500 BC; Barker 2006; Zarins 1990). Mobile pastoral activities diffused and mutated from the Levant northwest to Europe and eastward into Iran, along with village agricultural strategies, by the sixth millennium $\mathrm{BC}$ at the latest $-\mathrm{a}$ complex process beyond the scope of this article (Harris 1996; Meadow 1996; Zeder et al. 2006). However, in regions such as East Africa or the Arabian Peninsula, mobile pastoralism clearly predated agriculture as the earliest food-producing strategy (Harrower, McCorriston, and D'Andrea 2010; Marshall and Hildebrand 2002).

In the western part of Eurasia, domesticated cattle, sheep, and goats were part of Neolithic agricultural economies of the circum-Pontic region by at least the fifth millennium BC (Kotova 2008). These agricultural communities represent the likely sources for domesticated animals later adopted by specialized pastoralists in the mid-fourth millennium $\mathrm{BC}$ in the Caucasus and the trans-Caspian territories (Benecke 1997). Distinct from the process in the western parts of Eurasia, the specialized ecological strategies and interactive networks that supported the growth of mobile pastoralism in the central and eastern steppe regions appear to have evolved among mobile hunters. By comparison, western steppe pastoralism appears to have been based largely on short-range cattle herding, while eastern pastoralism was predominantly supported by vertically transhumant sheep/goat herding between mountains and lowlands (Shilov 1975; Vainshtein 1991). Along the western periphery of the steppe, grain agriculture provided a complementary resource that further distinguishes the economy of pastoralist groups north of the Black Sea. In the eastern steppe regions, grains were not raised as subsistence crops until the mid-first millennium BC (Miller-Rosen, Chang, and Grigoriev 2000), although new evidence indicates that millet and wheat were likely exchanged as commodities by $2300 \mathrm{BC}$ (Frachetti et al. 2010). Furthermore, the process of horse domestication in the north-central steppe zone-an undeniably catalytic innovation for Eurasian societies in that regionscores an economic divide between the eastern and western forms of mobile pastoralism in the fourth millennium BC.

At the outset, these observations imply that the emergence of mobile pastoralism in the eastern steppe region differed from that in the central region and that both differed from that in the western region. In each case we must distinguish between the complex pathways of introduction or adoption of domesticated animals and the emergence of a specialized socioeconomic adaptation based in mobile herding (Bernbeck 2008). In the following sections, I detail the rise of these mobile pastoralist economies across the steppe in the fourth to third millennium $\mathrm{BC}$ on the basis of three interrelated factors: (1) the source (or origin) of domesticated animals and the chronology of their intensified exploitation; (2) the ecological strategies of regional mobile pastoralists; and (3) the cohesion of pastoralist populations vis-à-vis trade, interaction, or migration. The western, central, and eastern steppe zones are addressed in turn before I present a model of interaction to illustrate their collective influence on Eurasian prehistory.

\section{Early Pastoralism in the Western Steppe Zone}

The western steppe region extends from the east banks of the Dnieper River (roughly) to the Ural Mountains and northward from the Black Sea littoral to the forest-steppe ecotone (fig. 1). This region is defined ecologically and in accordance with what David Anthony calls a "persistent cultural frontier" (Anthony 2007:104). By the start of the fifth millennium BC, agropastoralist communities occupied most of the western steppe territory north of the Black Sea. For example, archaeological evidence from hundreds of sites in the Ukrainian steppes documents large "Tripolye-Cucuteni"-type settlements, where societies cultivated wheat, barley, and (limited) broomcorn millet and bred cattle, sheep/goats, and pigs for primary consumption and "secondary products" (Chernysh 1982; Dolukhanov 2002; Pashkevich 2003; Rassamakin 2002).

Contemporary communities of hunters living east of the Don River likely exchanged material culture with these villagers, as reflected in the regional distribution of shared Eneolithic ceramics and burial styles across the trans-Caucasian plains (Rassamakin 1999). Most groups living along tributaries of the Don and Donets rivers and throughout the southern periphery of the forest-steppe zone, however, crafted locally differentiated economies by exploiting local hunting ranges, wild plants, and river resources across diverse ecological niches of the region (Popova 2009; Shilov 1985; Shishlina 2008).

Late-fifth-millennium-BC communities living on the drier north Caspian steppe were generally more mobile, hunting seasonally and living in campsites that included semiannual bases as well as more permanent settlements (Shishlina 2008: 224). The faunal record from the year-round settlement of Tentek-sor (4500-4000 cal BC) reflects a hunting strategy of mainly Asian wild ass (Equus hemionus kulan; 85\%) as well as antelope (Siaga tatarica; 5\%), aurochs (5\%) and a few wild horses (Barynkin and Kozin 1998:71; Kuz'mina 1988:175). Domesticated sheep and cattle were not recovered in sites of this time period. On the basis of faunal evidence, the economic division between village agroherders and mobile hunting groups across the western steppe persisted until the start of the fourth millennium BC.

Around 4200 BC, on the plains east of the Dnieper River and north to the forest-steppe frontier, so-called post-Mariupol and Sredny Stog-type villages reflect economic conti- 
nuity with the agriculture and short-range herding evident earlier in that region (Kotova 2008; Telegin 2002). Sites of the early fourth millennium BC in the arid Black Sea steppes, such as Moliukhor Bugor and Derievka, also provide evidence of hunting communities that kept some domesticated animals (Anthony 2007:247). Likewise, the trans-Caucasus and Volga River basin were home to hunting communities, subsumed under the "Khvalynsk" cultural typology, that supplemented their economies with domesticated animals to a small degree (Kuz'mina 1988). The limited use of domesticated animals (typically less than $10 \%$ of fauna) at sites such as Kyzl-khak II, Kurpezhe-molla, and Kara Khuduk I (3900-3700 cal BC) suggests a period of "auditioning" of new herding strategies among groups whose economy and regional ecology were still largely shaped by hunting during the fourth millennium BC (Barynkin 1998; Barynkin and Vasil'ev 1988).

Since these groups were primarily hunters, their seasonal mobility strategies were probably crafted to exploit the local diversity of wild resources in the north Caspian region (Shishlina 2008:225). The patterns of regional mobility later associated with specialized mobile pastoralists may have been derived from the mobile hunting strategies that prevailed during the early fourth millennium BC in these areas. Nevertheless, the low percentages of domesticated animals in faunal assemblages recovered from sites in the north Caspian steppe and trans-Caucasus do not indicate a specialized mobile pastoralist economy among any communities of the western steppe during the first half of the fourth millennium BC (Kuz'mina 1988).

Taken as a whole, the archaeological and faunal evidence of the Eneolithic period (ca. 5000-3200 BC) in the western Eurasian steppe zone illustrates the development of locally adapted economies among groups living in diverse ecological niches (fig. 2). Steppe populations from the Dnieper River to the Donets show increasing exploitation of domesticated cattle derived from Eneolithic agropastoralist communities living in the soil-rich areas of the circum-Pontic. More mobile groups farther to the east initiated their transition directly from hunting to (limited) herding without a significant engagement in agriculture, although the influence of western agropastoralists may yet be understated.

The end of the fourth millennium BC in the western steppe signals the emergence of the region's earliest specialized mobile pastoralist communities, coincident with the transition to the Bronze Age. The early Bronze Age (3200-2600 BC) in the western steppe is associated with a material-cultural category known as the Yamnaya (or pit-grave) culture (Merpert 1974; Rassamakin 1999; Shishlina 2001, 2008:230). Considering paleoethnobotanical data, faunal evidence, and regional ecology, Shishlina (2008:230) concludes that the "economic potential of mobile pastoralism seems to have been developed by the preceding [Eneolithic] population, which tried to exploit specific steppe environmental areas. But it was not until the appearance of Yamnaya people [sic], that this economic system of an absolutely new type became dominant."
The intensification of mobile pastoralism in the western steppe is most commonly explained as a response to panregional environmental shifts during the fourth millennium BC (Kremenetski 2003). However, if the documented climatic changes of the mid-fourth millennium BC resulted in largescale shifts in the region's ecological character (especially pasture resources), we might expect all groups in the region to align their diverse economic strategies in a more homogenous adaptation (Marshall and Hildebrand 2002). Apparently, the ecological diversity of the western steppe was not directly affected in terms of pasture productivity and distribution, at least not enough to bring about major shifts in mobility patterns or introduce wholesale shifts to a particular herd type or strategy.

The variety of archaeozoological signatures associated with Yamnaya-type sites suggests that using a singular economic description for the populations living across the western steppe oversimplifies the diversity of strategies in play at the start of the third millennium BC (Anthony 2007:322; Shishlina 2008:235). Burials provide the vast majority of evidence for the reconstruction of Yamnaya pastoralism (Shilov 1985), and by comparing the archaeozoological remains from burials with the few known Yamnaya settlement data, a different focus on domestic animals is evident in each context. For example, the archaeofauna summarized from Yamnaya burial kurgans (tumuli) illustrates roughly 65\% sheep/goats among interred domesticates (Shilov 1985), whereas data from the settlement Mikhailovka II show more than $60 \%$ domesticated cattle and 30\% sheep/goats (Korobkova and Shaposhnikova 2005:252). Beyond the inherent differences between burials and settlements, the westernmost borders of the Yamnaya cultural area are associated with agropastoralist cattle herders, while the populations occupying the eastern (Caspian) steppe regions appear more reliant on mobile herding of sheep/goats (Shishlina 2008:236-237). Such regional diversity in the third millennium BC was recognized in even the earliest conceptualizations of the Yamnaya typology (Merpert 1974). Yet in all cases, we are comparing imperfect and patchy archaeological data from inconsistently sampled contexts (Morales Muñiz and Antipina 2003).

Rather than equating the Yamnaya period with a holistic transition from one monolithic economy to another, a closer reading of the archaeology of the western steppe illustrates a transition rooted in strategic responses to particular ecological conditions on the part of local populations (Ingold 2000:175). Although affected partly by localized changes in the environment (Kotova 2008), mobile pastoralist strategies were also shaped by the expanding dynamics of social interaction and economic diffusion. Below, I argue that interactions surrounding exchanges of commodities and resources represent a dominant catalyst for economic changes at the domestic level and an important factor for subsequent shifts in institutional organization in the western steppe at end of the third millennium BC (Antipina 1997). 
From Horse Herding to Mobile Pastoralism in the Central Steppe

As described here, the central steppe region is shaped primarily by the dominant drainage basins of the Tobol, Ishim, and Irtysh rivers. It is demarcated on the west by the Ural Mountains and the valley of the Ural River (which flows south to the Caspian); on the east it is shaped by the forests that distinguish the northeastern banks of the Irtysh River and by the rising elevations that change the steppe ecology along the "Altai edge" (Altai Krai). This definition is admittedly heuristic and lends itself to highlighting archaeological differences that distinguish the western, central, and eastern regions at the end of the Eneolithic era.

From 4500 to 3500 BC, Eneolithic communities living in the north-central territories of the Eurasian steppe (fig. 1) were predominantly hunters and fishers. These communities are traditionally associated with the "Atbasar" culture group, which is known mostly from small settlements centralized in the upper Ishim River valley and the low, rolling hills of the Tobol River basin (Kislenko and Tatarintseva 1999). Atbasar settlement types range from seasonal camps to more permanent villages, although investigations of site taphonomy typically reveal thin cultural layers and highly fragmentary archaeological assemblages. Scanty faunal remains make it difficult to categorize the use of domesticated animals, and thus little can be said about the possibility of early herding among these groups (Kislenko and Tatarintseva 1999:191).

The first documented communities in Eurasia to have exploited domesticated animals are associated with the late Eneolithic/early Bronze Age "Botai culture" (Zaĭbert 1993). At Botai, more than $99 \%$ of the total fauna was identified as horse (Levine 2005). According to recently published lipid analysis of ceramic pots from the type-site Botai (3600-2800 $\mathrm{BC})$, these north-central steppe communities raised domesticated horses for meat, milk, and probably for transport (Outram et al. 2009). Evidence of corralling and leather thong-smoothers imply that some horses at Botai were being controlled (Olsen 2006b). Although home to herders, Botaiculture villages appear to have been year-round settlements rather than seasonal campsites. Aspects of the north-central steppe economy are still debated, but most agree that horse domestication at Botai reflects an ecologically situated independent case of domestication.

The mid-fourth-millennium-BC economy in the central steppe region differed strongly from that of contemporary herding groups in the western steppe, who were antelope hunters, fishers, and incipient herders of cattle and caprines. Although fish was also a likely supplement to the diet of Botai groups (O'Connell, Levine, and Hedges 2003), bones of cattle and sheep are unknown from Botai-type sites (Benecke and von den Driesch 2003:73). Distinct from the hunters' campsites recorded in the Volga region and Caspian steppe, Botaitype villages were large, with substantial pit houses, and were most likely occupied on a year-round basis (Olsen 2003).
Similarities between Botai and other settlements in the region, such as Krasnyi Yar, illustrate the growth of a highly specialized autochthonous domestication process in open-steppe ecology dissimilar to the mobile and diversified economic strategies found farther west. Such large concentrations of horses are not reflected in any of the earliest forms of mobile pastoralism outside the central steppe zone.

The horse herders of the Botai culture themselves did not make a substantial change toward mixed-ungulate mobile pastoralism until the middle or late third millennium $\mathrm{BC}-$ roughly 1,000 years after horse domestication (Akhinzhanov, Makarova, and Nurumov 1992). Benecke and von den Driesch (2003) summarize the faunal evidence from middle Bronze Age sites in the central steppe (and elsewhere) and illustrate that steppe societies dependent on horse meat in the fourth millennium BC, such as those at Botai, illustrate either a rapid transition to the exploitation of cattle, sheep, and goats around $2500 \mathrm{BC}$ or that the sites are discontinuous (Kalieva and Logvin 1997). The few sites with continued occupation throughout the third millennium, such as Baladino and Sergeevka, also show concerted shifts in their archaeofaunal assemblages, indicating that the prevalent herding strategies across the region changed drastically from the Botai period (Akhinzhanov, Makarova, and Nurumov 1992).

The reason for the abrupt economic transition in the central steppe zone is not well understood. It may have been initiated by an acute localized shift in environmental resources or by a considerable change in the availability of wild horses in the region. The change in strategy around $2500 \mathrm{BC}$ was more likely related to a confluence of interactive pulses stemming from both western and eastern pastoralists in the mid-third millennium $\mathrm{BC}$. Although the domestication of horses evident in the north-central steppe in the mid-fourth millennium BC contributed a key innovation to Eurasian pastoralism in the long run, this advance was not felt en force in the eastern and southeastern steppe zones until perhaps the late second or even the first millennium BC (Frachetti and Benecke 2009; see also Kohl 2007:138). More significantly, the shift to cattle and sheep/goat pastoralism in the central steppe region may be traced to the nature of pastoralist mobility in neighboring regions, which fostered interactive ties among the eastern and western regions of Eurasia by the late Bronze Age.

The early third millennium $\mathrm{BC}$ appears to be a time when innovations from both eastern and western pastoralist groups gained currency over a wider territory. Thus, there may have been a simultaneous process of economic transformation and diffusion of technologies and associated ideologies between eastern, central, and western steppe pastoralists. As a result, horses came to occupy a key ideological role in shaping social institutions and economic growth among many pastoralist communities of Eurasia during the late third and second millennia BC (Outram et al. 2011). The spread of ideological associations of horses and wheeled vehicles with power and status was fostered by networks of interaction that grew along the edges of local pastoralist landscapes ranging from the 
western steppe to central China (Kelekna 2009; Linduff 2003). I illustrate how such alignments took form by reviewing the evidence for emerging pastoralism in the eastern steppe and along the IAMC.

\section{The Eastern Steppe and the IAMC}

The "eastern steppe"-the territory east of the Irtysh River over the Altai Mountains to the Yenesei River-may be a misnomer. This region might more appropriately be called southwest Siberia or, for reasons outlined below, the northern reach of the IAMC. Current archaeological data illustrate that the first documented societies to exhibit a specialized pastoralist economy in the eastern Eurasian steppe zone were sheep/goat herders living in and around the Altai Mountains, categorized archaeologically within the "Afanas'ev" material typology (ca. 3700-2700 BC; Kosarev 1984; Svyatko et al. 2009). Even though the steppe/grassland environment extends east beyond the Altai Mountains at least as far as Mongolia, the easternmost territory addressed here lies in the western piedmont and highland zones of the Altai Mountains and along the Yenesei and Irtysh rivers.

The "Afanas'ev culture" is known primarily from burial remains, and the economy is reconstructed almost exclusively from ritually interred animals. A few settlements are known, but these are far from comprehensively studied (Pogozheva et al. 2006). Early in the recovery of Afanas'ev burials, Vadetskaya documented bones of domesticated animals along with wild game that together illustrate a substantially developed pastoralist strategy of sheep/goat and cattle herding supplemented by hunting and fishing among these early Bronze Age communities (Vadetskaya 1986). Available data summarized from Afanas'ev burials illustrate, on average, $50 \%$ of interred taxa to be wild mammals, $24 \%$ to be domesticated sheep/goats, and $20 \%$ to be domesticated cattle (Shilov 1975).

By contrast, domestic faunal remains from the few important Afanas'ev settlements, such as Balyktyul, show $68 \%$ caprine, $13 \%$ cattle, and $8 \%$ horse (Alekhin and Gal'chenko 1995). At another Afanas'ev settlement, Kara-Tenesh, sheep make up $70 \%$ of domesticated fauna, while horse and cattle represent $7 \%$ and $11 \%$, respectively (Pogozheva et al. 2006: 23). ${ }^{1}$ Wild animals make up $27 \%$ of the total fauna. Comparatively, it appears that a herding economy, perhaps still incipient in form, was forming around the management of domesticated sheep/goats, while hunting (of highland ungulates and horses) remained a significant social factor, ${ }^{2}$ if not more economically productive among some eastern steppe groups.

There is little debate that Afanas'ev communities offer the

1. Minimum number of individuals $(\mathrm{MNI})=3$.

2. Alekhin and Gal'chenko (1995:22) suggest that the bone remains of horse in the Altai sites of the Afanas'ev culture were of domesticated animals. However, neither metric nor morphological data are provided to document their assessment, so a conservative view is that these animals may also have been hunted. earliest evidence for Eneolithic/Bronze Age herding in the eastern steppe region (Khazanov 1994). Since the discovery of Afanas'ev burials more than 80 years ago, however, the source of this pastoralist adaptation has been central to archaeological debates in the region. First, there are few Neolithic findings in the Altai region that show clear ties to the Afanas'ev material assemblage or burial traditions, so these pastoralists of the early fourth millennium cannot easily be traced to indigenous or local communities from a material perspective (Pogozheva et al. 2006). Thus, on the basis of apparent archaeological comparisons, scholars have long proposed an exogenous western source for Afanas'ev populations and by association their pastoralist economy (Okladnikov 1959).

For decades, the Afanas'ev culture has been considered to be derivative from the Yamnaya culture of the western steppe (Svyatko et al. 2009; Vadetskaya 1986). The discovery of wheeled carts and horses among Yamnaya burials led scholars to envision the pastoralists of the Caspian steppe region as more extensively migratory than current reconstructions indicate (Merpert 1974). A long-standing paradigm states that Yamnaya groups migrated more than 2,000 km across Eurasia and transplanted their specialized pastoralist economy and materials in the eastern steppe zone in the early third millennium BC (Danilenko 1974). At first, this argument was based on the relative chronologies of these groups, which until recently stemmed solely from the comparable ceramic forms and broadly analogous burial rites evident in each region. Furthermore, some have relied on craniometrics to suggest an occidental origin for Afanas'ev populations, but this line of evidence is wrought with issues beyond the scope of this paper (Good, forthcoming). In some cases, this model is uncritically reproduced in recent literature to explain apparent genetic affinities among later Bronze Age steppe populations (Keyser et al. 2009). This and other ancient DNA studies, such as those conducted at the burial site of Xiaohe in western China, note that the presence of western-Eurasian haplotypes in southwest Siberia is best explained by genetic drift dating between 20,000 and 10,000 years BP (Keyser et al. 2009:406; Li et al. 2010:10). However, these studies rely on archaeological models rather than clear DNA evidence to inform their subsequent interpretation that Rlala haplotypes found among eastern-Eurasian populations reflect later Bronze Age genetic drift from western Eurasia rather than drift from other regional genetic pools (such as south and central Asia), where they are also found in high concentration.

In recent years, a concerted program of radiocarbon dating of both Yamnaya and Afanas'ev sites by German and Russian archaeologists (among others) has enabled a substantial recalibration of the early Bronze Age chronology of the western and the eastern steppe zones (Anthony 2007; Görsdörf, Parzinger, and Nagler 2001; Rassamakin 1999; Shishlina 2004). Radiocarbon dates from Afanas'ev burial monuments in the Minusinsk Basin and Altai Mountains are generally now calibrated between 3700 and 2500 BC (Görsdörf, Parzinger, and Nagler 2004; Svyatko et al. 2009), while Yamnaya sites are confidently 
dated from 3100 to 2400 BC (Chernykh 2009). Some have even suggested a start of the Afanas'ev cultural type as early as ca. $3800-2400 \mathrm{cal}$ BC $(2 \sigma)$, on the basis of radiocarbon dates from the Altai region (Kiryushkin, Grushin, and Panin 2009:121). A recent review of Afanas'ev radiocarbon data suggest that the earliest dates may reflect an "old wood" effect, prompting a more conservative chronology for the Afanas'ev floruit from 3300 to 2500 cal BC (Svyatko et al. 2009).

Likewise, new chronological periodization within western Eurasia has ignited a breakdown in the academic understanding of the Yamnaya typology itself (Chernykh 2009; Rassamakin 1999; Telegin 2002). In keeping with the traditional model of Yamnaya origins for eastern pastoralism, there are proponents of the idea that Yamnaya cultural "traits" were evident in the western steppe by 3600 BC (Polyakov and Svyatko 2009). Furthermore, Anthony has cited material similarities between western groups of the fourth millennium BC and Afanas'ev assemblages to suggest that an earlier "culture group"-the Repin culture-may have made the extensive migration east (Anthony 2007:305).

Thus, stylistic parallels between western steppe sites and Afanas'ev ceramics and burial styles remain as the lasting argument for interrelationships among these regional communities (Stepanova 2009). The often-cited "flexed" burial position of bodies typical for Yamnaya graves is also common in Afanas'ev burials, which has bolstered arguments for the westward expansion of Yamnaya communities. In fact, the body position is also encountered in pre-Yamnaya Sredny Stog and Khvalynsk cemeteries in the west, another reason some propose that Afanas'ev burial rituals may have a source in earlier western communities. Published burials from the southern central-Asian site of Sarazm (ca. 3500 BC) also share this burial position (Avanessova and Dzhurakulova 2008; Lyonnet 1996), complicating the debate about the purported origins of Afanas'ev burial types.

Beyond the debates about chronologies and typologies of these respective cultural groups (Kohl 2009b), the archaeological evidence in the eastern steppe shows that well-adapted pastoralists were living in the Altai region at least 300 years before comparable specialization is evident in the western steppe. More archaeozoology is needed, and because these regions are separated by nearly $2,000 \mathrm{~km}$, there are likely many complex pathways that fostered economic changes in both regions at the end of the fourth millennium BC. Although more direct demographic processes within an interactive arena forming in the late third millennium $\mathrm{BC}$ may prove to overlie these earlier local systems, we might look to more direct indexes to compare the earliest pastoralists of the western steppe with those of the east to find a more informative perspective on their differentiated development or interrelated genesis.

Interregional economic comparisons of any of the fourthto third-millennium-BC eastern (Afanas'ev) pastoralists with communities of either the central (Botai-Tersek) or western culture regions illustrate highly distinctive faunal signatures and associated economic practices. Figure 3 maps the com- parative faunal assemblages among fourth- and third-millennium-BC communities across the steppe on the basis of summarized available evidence from settlement contexts. One must be careful in interpreting this inconsistent and regionally patchy archaeozoology, as a number of taphonomic processes may affect the calculated percentages of animals represented (Morales Muñiz and Antipina 2003). Yet as representative samples, these data show considerable dissimilarities in the focus of herd exploitation among early pastoralists living in the western, central, and eastern parts of the Eurasian steppe.

Synthetically, mid-fourth-millennium-BC communities living in the western steppe were either agropastoralists (e.g., Mikhailovka II), hunters (e.g., Kyzl-khak II), or, in some areas, more heavily engaged as cattle pastoralists (e.g., late Maikop). By the third millennium BC, western steppe pastoralists were using short-range seasonal migrations between river valleys and open-steppe contexts, variously exploiting relevant ecological microniches (Shishlina 2008). By contrast, herders in the Altai region were vertically transhumant sheep/goat herders, and they continued to hunt and fish. Eastern pastoralist communities occupying the steppe river basins also exploited "forest islands" for both pasturing and hunting large game (Anthony 2007:309; Shilov 1975:6). Detailed reconstructions of Afanas'ev settlement and pastoralist ecology are not well developed because of gaps in evidence, but eastern pastoralists likely used the seasonally variable ecology between low piedmont valleys and high mountain meadows to cultivate their herds (Vainshtein 1991). In contrast to both eastern and western pastoralists, the people of the central steppe regions were semisedentary horse hunters and horse herders who exploited the rolling hills and valleys of river valleys and forest edges with no sheep, goats, or cattle to speak of before the midthird millennium BC (Benecke and von den Driesch 2003). Regional networks expanded in the later Bronze Age and contributed to greater regional similarity in steppe pastoralist strategies, but the main types of domesticated animals and their relative proportions, which shaped the earliest herding societies in the fourth and third millennia $\mathrm{BC}$, diverge substantially when compared from west to east (fig. 4).

\section{The IAMC: A Vector of Early Pastoralism in Eastern Eurasia}

If western steppe pastoralists were not the likely source of Afanas'ev pastoralism in the eastern steppe, what was the springboard of eastern steppe herding economies? Where can we trace their source of domestic animals, and what brought on the intensification of mobile pastoral strategies in the Altai and southwest Siberia? Without obvious antecedent communities and given the disjointed early Bronze Age economies evident across the Eurasian grasslands, we may fruitfully look to neighboring regions, minimally for the source of domesticated animals and possibly to document a developmental trajectory of the ecological strategies common to mountain pastoralists in eastern Eurasia. Recent research suggests that 


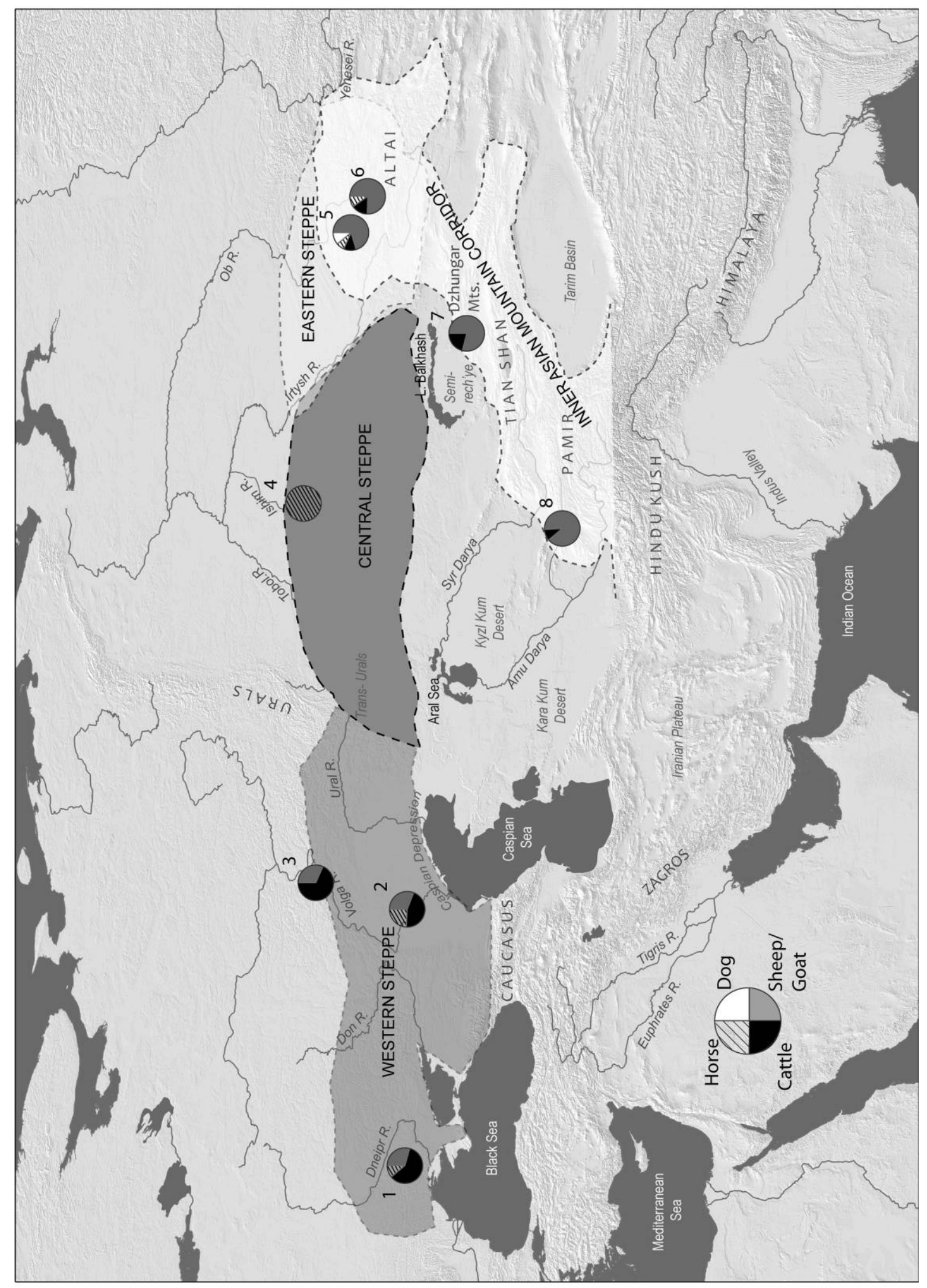

This content downloaded from 129.237.046.008 on July 18, 2016 08:54:26 AM 
part of the answer to the puzzle may lie with mobile communities that lived in the regions where few have sought to look for domestic diffusion: south along the IAMC.

For the purpose of this argument, the IAMC starts in the Hindu Kush Mountains of Afghanistan, runs through the Pamir, Tian Shan, and Dzhungar mountains, and ends at the Altai Mountains of southwestern Siberia (fig. 5). Mountain altitudes here commonly reach above $6,000 \mathrm{~m}$, and extreme seasonality makes the region difficult to exploit. This territory's rugged terrain can pose a deadly threat to the maladapted visitor. So, like other extreme environmental settings (such as deserts), the IAMC demands specialized strategies for exploitation and even then has rarely supported large populations when compared with more ecumenical habitats (Aldenderfer 2006). As a result, inner Asian mountain populations have long been depicted as disconnected, remote, and peripheral to the primary currents of socioeconomic change among civilizations (Stein 1925).

Decades of research illustrate that outside the mountain zones, agriculture and animal herding were long a part of the Neolithic economies of populations living in oasis and valley communities across southern central Asia (Turkmenistan, Uzbekistan, and parts of Tajikistan; Isakov 1991; Moore et al. 1994). The huge mountain ranges of the Pamir and the Tian Shan might have prohibited the spread of these domestic strategies northward into the steppe, and without a regulated system of exchange, the nomadic steppe world and the settled agricultural world of southern central Asia may have been destined to remain separated until late in the second millennium BC (Vinogradova 1993).

Newly converging lines of evidence suggest that pastoralist communities living throughout the IAMC were more interconnected than the "barrier model" might imply (Chen and Hiebert 1995). For example, recent genetic analyses of a wide distribution of wild and domestic sheep across Eurasia demonstrate that wild-sheep species from southeastern Kazakhstan are genetically distinct from other Eurasian wild sheep but that domestic sheep from this region are genetically homogeneous with those found in southern central Asia, namely, Tajikistan (Hiendleder et al. 2002). The separation of the genetic character of regional sheep cohorts is generally attributed to repeated reintroductions of wild-sheep genes into domestic herds. Thus, if domesticated sheep had diffused eastward from the Caspian region, we would expect greater homogeneity between European breeds and eastern-Eurasian breeds, as both would contain genetic markers of wild sheep introduced in Europe after the initial domestication event in the Near East some 9,000 years ago. Instead, Hiendleder et al. (1998) illustrate distinct clades of European and centralAsian sheep, while Syrian sheep represent the closest genetic neighbors of domesticated central-Asian sheep (Hiendleder et al. 2002, fig. 4b). The early genetic separation from European breeds contradicts the idea of a late introduction of sheep to eastern Eurasia from the circum-Pontic or Caspian steppes, because these two regions would otherwise show genetic signatures closer to those in the east.

Furthermore, recent studies of retrovirus integrationswhich are genetic markers that illustrate phylogenic relationships through time- demonstrate that a diversity of introduced proviruses among European sheep breeds can be related to polymorphic insertions (from wild populations) made after the original domestication event of southwest-Asian sheep (Chessa et al. 2009). Chessa and colleagues demonstrate that as sheep were integrated into the local economies of Europe, local wild sheep were interbred with wild populations, developing distinctive retroviral combinations. By contrast, Near Eastern sheep appear to be nearly retrovirally homogenous with domesticated sheep in Pakistan and China, which the authors interpret as evidence for a "direct migratory link of domestic sheep between these areas" (Chessa et al. 2009:533). A herd base in sheep/goats is particularly representative of the early pastoralist strategies reflected statistically by fauna from Afanas'ev burials of the Altai and is documented as the dominant strategy of prehistoric herder communities to the south of the steppe along the IAMC (Frachetti and Benecke 2009). Closer examination of faunal assemblages from early Bronze Age sites throughout the mountain corridor illustrates surprisingly similar herd composition and ecological strategies (fig. 2).

A key site in the discussion about fourth-millennium-BC domestic economy along the IAMC is the Eneolithic/early Bronze Age site of Sarazm (ca. 3500-1500 BC; Isakov 1991). Sarazm is located along the lower Zerafshan River valley in Tajikistan and is the northernmost site in central Asia with direct evidence for both agriculture and herding in the fourth millennium BC. Paleoethnobotanical remains from Sarazm document free-threshing bread wheat (Triticum aestivum) and barley (G. Willcox, unpublished report; ${ }^{3}$ Razzokov 2008), and copious stone grinders and pestles index a domestic economy heavily engaged in processing grains. The site's fauna reflects more than $87 \%$ sheep/goats, $10 \%$ cattle, and less than $1 \%$ dogs (analysis, by Kasparov, in Razzokov 2008:72). In comparison with contemporaneous agricultural villages in south-

3. Sarazm Paleoethnobotanical Report, for the Institut de Préhistoire Orientale, Centre National de la Recherche Scientifique, Paris.

Figure 3. Geographic comparison of representative domestic faunal assemblages from early Bronze Age settlements of the western, central, and eastern steppe regions and along the Inner Asian Mountain Corridor. 1, Mikhailovka II; 2, Kyzl-khak II; 3, Kara Khuduk I; 4, Botai; 5, KaraTenesh; 6, Balyktyul; 7, Begash; 8, Sarazm. A color version of this figure is available in the online edition of Current Anthropology. 


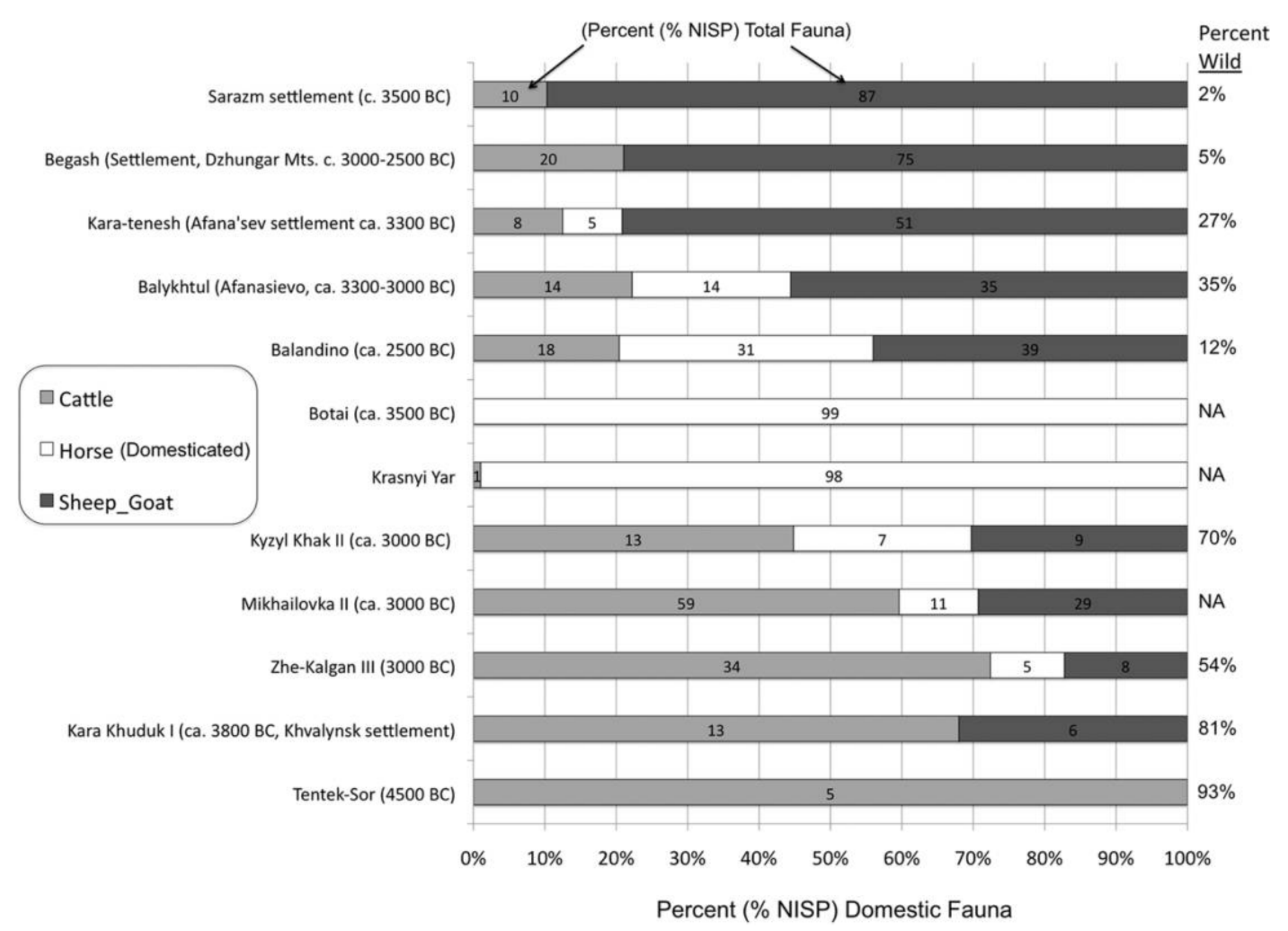

Figure 4. Comparative percentages of domesticated cattle, horses, and sheep/goats from settlements of the fourth and third millennia BC across the Eurasian steppe. Inset numbers represent the percentage of total fauna reflected by domesticated species in each case. Sources are cited in the text. NISP, number of identified specimens.

ern delta oases and the arid plains of the Zerafshan River fan (e.g., Ilgyn-tepe), the prevalence of sheep/goat over cattle at Sarazm is reflective of herding more common among mountain groups (Razzokov 2008:73). Given Sarazm's location in a high-altitude valley, this may reflect an emerging relationship with mountain groups.

No clearly documented pastoralist campsites of the fourth or third millennium BC in the Zerafshan Valley are directly related to Sarazm. This is a frontier in need of new research. Third-millennium-BC pastoralism in the region can be inferred only from a few "steppe-type" burials, one recovered directly at Sarazm (Lyonnet 1996:67) and another recently documented at the site of Jukov (Avanessova and Dzhurakulova 2008). Material from both sites reflects atypical ceramics categorized by the analysts as broadly "Afanas'ev type" with local admixtures and dating to the mid-fourth millennium BC (N. A. Avanessova, personal communication, 2011). The burial position at Sarazm is reportedly flexed, and apparently no human remains were documented at Jukov. Fauna from Jukov included sheep/ goats and cattle as well as wild animals, causing Avanessova and Dzhurakulova to interpret these burials as clear signs that mobile pastoralist communities were active throughout the Zer- afshan region in the fourth millennium BC (Avanessova and Dzhurakulova 2008:29).

The few known mountain settlements of this time period in Tajikistan show substantial evidence of lithic tools (presumably for hunting and processing meat), but the archaeozoological details remain poorly documented (see Ranov and Karimova 2005 for a general treatment of the Neolithic of the Pamir region). For example, at the site of Kangurt-tut in the eastern Pamir Mountains, limited evidence exists for the emergence of a semidomesticated economic strategy in the late fourth millennium BC (late Hissar period). Vinogradova, Ranov, and Filimonova (2008) cautiously interpret the scanty botanical and faunal remains there as evidence for a transitional economic phase, for which they coin the term "prepastoralism" (p. 87).

Given these enticing lines of evidence from the Pamir region, pastoralist communities probably exploited the pastures of the upper Zerafshan Valley in the late fourth millennium BC. By the early third millennium BC, more data are available to illustrate incipient networks of trade in these highland areas for the extraction of metal ores or precious stones (Kenoyer 2008; Law 2006; Parzinger and Boroffka 2003) and for well- 


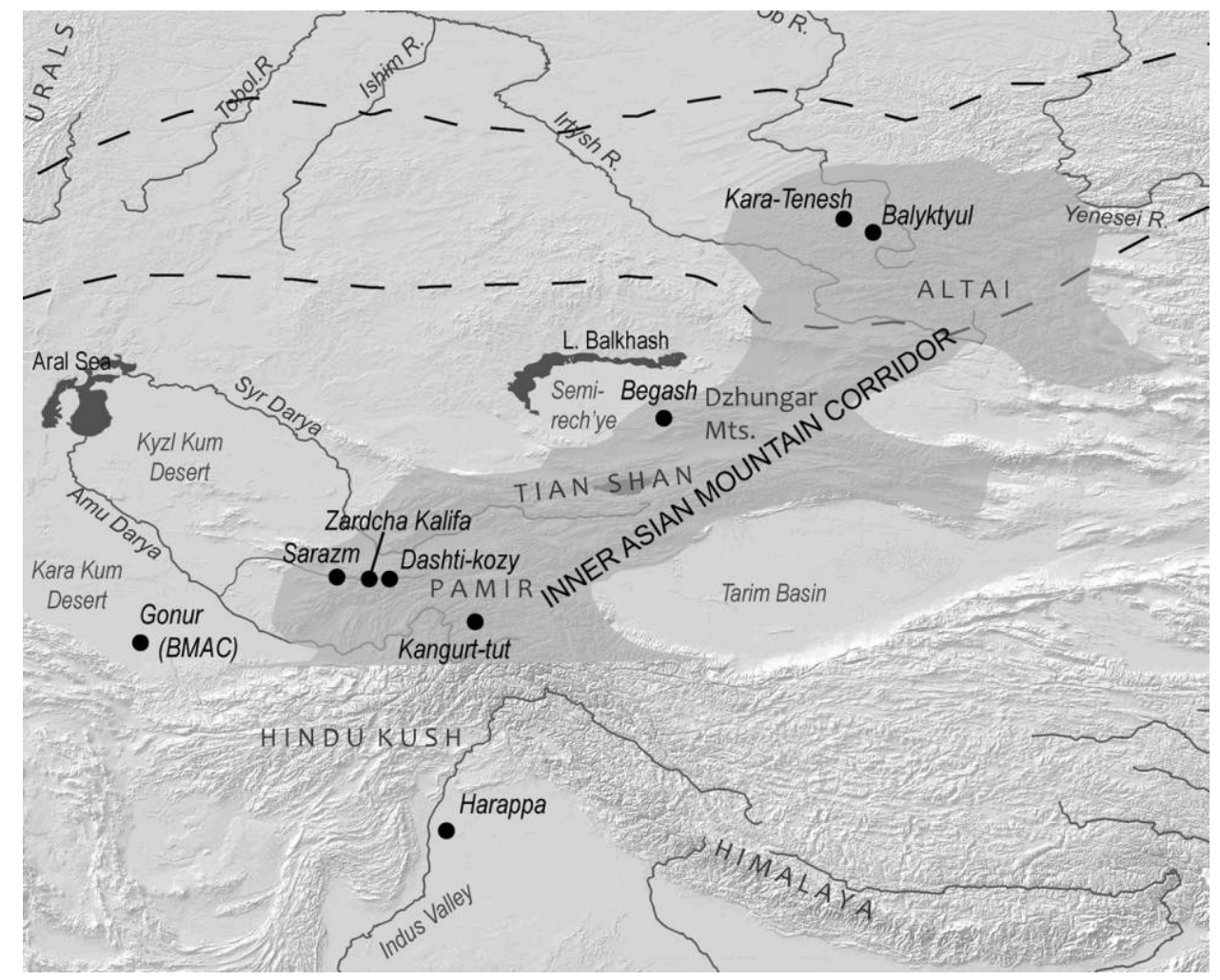

Figure 5. Geographic setting of select fourth and third millennium BC archaeological sites of the Inner Asian Mountain Corridor. BMAC, Bactria-Margiana Archaeological Complex. A color version of this figure is available in the online edition of Current Anthropology.

established pastoralist settlements in the Dzhungar Mountains, located equidistant between the Altai Mountains and the Pamirs. These examples indicate the possibility that earlier pastoralist communities were more prevalent throughout the IAMC as well.

Archaeological remains from the early/middle Bronze Age settlement of Begash-located in the Dhzungar Mountainsillustrate broad affinities with assemblages known throughout the IAMC (Avanessova 1996). Chronologically, Begash's earliest cultural layers (phase 1a) are accelerator mass spectrometry-dated 2500-2000 cal BC, although limited radiocarbon evidence suggests that the site may have been in use at the start of the third millennium BC. ${ }^{4}$ In addition, closed-mouth globular ceramic vessels, lithic material, and stone implements from Begash are comparable with materials recovered from mountain sites directly to the north and south (Frachetti and Mar'yashev 2007). Admittedly, the material affinities linking Begash to sites to the north or south are too few at present to demonstrate a clear pattern of interaction across the mountain corridor. Economically, however, new evidence for do-

4. $4220 \pm 220$ BP (AA52926; wood charcoal, 3100-2450 cal BC, calibrated with OxCal at $1 \sigma)$. mesticated grains at Begash and comparative herd structures evident among pastoralist sites in the Altai and Dzhungar mountains and agricultural sites such as Sarazm warrant a closer comparison of domestic strategies along the IAMC.

The early Bronze Age levels at Begash also provide the earliest evidence of emerging exchange networks along the IAMC and into western China. Recently published botanical evidence from Begash illustrates the ritual use of domesticated wheat and broomcorn millet in cremation ceremonies around $2300 \mathrm{cal}$ BC (Frachetti et al. 2010). The archaeological context of the Begash wheat and millet-a cremation burial-does not indicate that the grains were grown locally at this time. Rather, free-threshing wheat, most typical in the southern reaches of central Asia and the Indus (Fuller 2001), apparently was passed northward along the foothills of the IAMC to be used ritually at Begash. Although still speculative, this pathway may have continued east along the Tian Shan range and eventually through the Hexi Corridor, resulting in the introduction of compact bread wheat in China by the mid- to late third millennium BC (Flad et al. 2010). In the opposite direction, it appears that broomcorn millet, one of China's earliest domesticates and unknown in southwest Asia until the second 
millennium BC, was also being trafficked along this IAMC pathway by pastoralists from Begash. The appearance of both wheat and millet at Begash suggests that the geography of the mountain corridor almost certainly extended eastward from the central Tian Shan to Gansu Province, situating sites such as Begash at the crossroads of extremely wide networks among Eurasian communities by the third millennium BC.

At Begash, domesticated plants were used only in a ritual context. Faunal data illustrate that the site's occupants were engaged in a fully developed mobile pastoralist economy dominated by sheep and goat herding. In the third millennium BC, sheep/goats represented more than $75 \%$ of the fauna, with cattle constituting approximately $15 \%$. Unlike contemporary sites in the western Eurasian steppe, at Begash horses were not present until the second millennium $B C$, and even then they represented less than $4 \%$ of the assemblage. Horses appear to have been relatively insignificant to the pastoralist strategy of eastern Eurasia's mountain herding communities until the mid-first millennium BC (Frachetti and Benecke 2009). Recalling the respective percentages of domesticated animals from Afanas'ev settlements and Sarazm, the faunal data from Begash contribute to a consistent picture of herding strategies across the mountain corridor in the third millennium BC that is fairly distinctive from that recorded in the western and north-central steppe.

From the perspective of pastoralist ecology, Begash illustrates a pattern of seasonal vertical transhumance exploiting orographically distributed ranges from arid lowland plains to rich highland pastures (Frachetti 2008). This ecological structure and pastoralist strategy are documented both archaeologically and ethnographically from the Pamir Mountains to the Altai Mountains (Goloskokov 1984; Khazanov 1978; Masanov 1995; Shahrani 1979; Vainshtein 1991). In reconstructing the social economy in the Dzhungar Mountains, I have proposed that mobile pastoralist societies created active networks of interaction throughout the mountains of inner Asia by the start of the third millennium BC (Frachetti 2008). This interaction was facilitated by the geographic pattern of transhumant seasonal mobility, which located communities in shared territories at various times of the year (Beck 1991).

The development of mountain-adapted strategies may be traced to the patterns of mountain hunting indicated at sites along the IAMC, representing another point of comparison between ecological adaptations of early pastoralists in the Altai, Dzhungar, and Pamir mountains (table 1). Specifically, the evidence for hunting at Afanas'ev sites and at Begash illustrates a common exploitation of mountain and lowland (arid-zone) mammals, suggesting broadly analogous ranges of mobility on the part of these respective communities. We do not have good faunal records from any mountain sites from the fourth to third millennium BC in the upper Zerafshan region, so we can only speculate that mountain populations there would have hunted a similar range of highland animals.

The wild-animal assemblage from Sarazm shows an absence of animals endemic to high-altitude ecologies. This is not surprising, because the agriculturalists of Sarazm were neither mountain pastoralists nor hunters and apparently did not exploit the high mountains to a great degree. Instead, gazelle is the dominant wild animal at Sarazm, which suggests that the population was engaged in limited hunting in the semiarid lowland plains (Razzokov 2008). If local mountain groups (hunters or incipient herders) were hunting in the same way documented for pastoralists in the Altai and Dzhungar mountains in the early third millennium BC, their strategies would have brought them into contact periodically with the lowvalley inhabitants of Sarazm. Thus, even in a prepastoralist phase, mountain groups living in the upper Zerafshan Valley would have needed only a small transition to incorporate domesticated animals into their already well-adapted pattern of mountain transhumance.

Considering the genetic and economic reconstructions presented above, I suggest that local groups living along the IAMC were more interrelated in their development of pastoralism in the late fourth and early third millennia BC than previously recognized. Mountain communities who shared resource catchments with sites such as Sarazm could easily adopt domesticated animals from agricultural communities and diffuse these strategies quickly throughout the inner Asian mountains. The seasonal land-use patterns that underpinned their hunting and foraging also would have been easily adapted to incipient herding activities. Mountain populations with economies in transition between hunting and pastoralism ("incipient pastoralists") may have passed this strategy through interactive networks along the IAMC by the midthird millennium BC.

Table 1. Predominant wild fauna recovered from fourth- to third-millennium-BC sites in the Inner Asian Mountain Corridor

\begin{tabular}{|c|c|c|c|}
\hline Site & $\begin{array}{l}\text { Lowland } \\
\text { (semi)arid plains }\end{array}$ & Midaltitude riparian/forests & $\begin{array}{l}\text { Highland } \\
\text { meadows/forests }\end{array}$ \\
\hline \multicolumn{4}{|c|}{ Begash (phases 1a, 1b; Frachetti and } \\
\hline \multicolumn{4}{|c|}{ Afanas'ev (summarized burial data from } \\
\hline Shilov 1975) & Saiga tatarica & $\begin{array}{l}\text { C. elaphus, Capreolus capreolus, Moschus } \\
\text { moschiferus }\end{array}$ & C. elaphus \\
\hline
\end{tabular}


Although early evidence for highland-lowland interaction is scanty in the third millennium $\mathrm{BC}$, more-compelling evidence for the interaction of pastoralist communities and lower-elevation agriculturalists by the second millennium BC is evident in the Zerafshan Valley (Bobomulloev 1998). Bronze Age burial sites such as Zardcha Khalifa and Dashti Kozy contained ceramics and metallurgy with obvious parallels to second-millennium-BC pastoralist sites throughout the IAMC (Bobomulloev 1998). Although no reliable evidence to illustrate a subsistence economy was recovered from these burial sites, they clearly illustrate a material tradition distinct from that of contemporary agriculturalists at Sarazm or farther into the lowlands (Litvinkskij, Okladnikov, and Ranov 1962).

More evidence is needed to test the archaeological affinities among communities along the IAMC. Nevertheless, current archaeology from the region suggests that a significant interaction network of both pastoralists and nonpastoralists was fostering complex institutional ties throughout the mountains (and across Eurasia more generally), beginning in the late fourth and third millennia BC (Chen and Hiebert 1995). Although beyond the geographic scope considered here, the IAMC may also have been a key conduit for Bronze Age developments farther into east Asia and Mongolia. A model illustrates how antecedent ties (Granovetter 1973), such as those among different regional pastoralist communities of the IAMC, served to generate durable "nonuniform" institutional growth across Eurasia by the second millennium BC.

\section{Nonuniform Institutional Complexity in Bronze Age Eurasia: Diverse Alignments of Commodities and Ideology}

Early mobile pastoralist economies were essential to the formation of extensive networks of interaction across Eurasia and along the IAMC because the ecological demands of their pastoralist strategies-moving herds across restricted environments-conditioned arenas of exchange among neighboring communities (Frachetti 2008). According to this idea, specific institutions evident among early regional pastoralists in the western, central, and eastern steppe became loosely aligned through commodity trading and regional social interaction. By the second millennium BC, regionally developed ideological and political institutions relating particular technological innovations with political status grew along differentiated channels of interaction far across Eurasia (Kohl 2008). Commodities such as metals, precious stones, and shells and innovations in riding and transport (e.g., chariots) all played a role in an ever-expanding and varied economic social field that both fueled and was fueled by political and ideological interests (Kohl 2008). The third- to second-millennium-BC expansion of wheeled technologies in the form of carts, wagons, and eventually chariots in the western steppe region converged with analogous innovations and expansions in eastern and southern Eurasia to foster a panregional ideo- logical relationship between political leadership, chariots or carts, and access to commodities and resources.

Disk-wheel clay models of the Tripolye culture (ca. 3500 BC) represent the earliest known evidence of wheeled vehicles in the western Eurasian steppes (Rassamakin 2002), while later Yamnaya-period burials (ca. 3000-2800 BC) contain remnants of four-wheel bullock carts, which illustrate a clear association between carts and wagons and ritual contexts around the beginning of the third millennium BC (Anthony 2007:65-72; Korvin-Piotrovskii and Movsha 1999). In the Indus Valley, the site of Harappa provides evidence for an independent development of wheeled carts in the fourth and third millennia BC. A fragmentary clay model of a cart wheel dating to the middle fourth millennium $\mathrm{BC}$ is augmented by later (Kot Diji phase, 2800-2600 BC) examples illustrating that two-wheeled bullock carts were in use in the Indus Valley during the third millennium BC (Kenoyer 2009). Kenoyer (2009) sees these developments as wholly independent of those in western Eurasia, an interpretation supported by his detailed analysis of cart styles and yoke technology.

The mid-third-millennium-BC burials at Altyn-tepe and Anau III in southern central Asia have also produced clay models of four-wheeled wagons pulled by Bactrian camels (Kenoyer 2009:15; Masson and Sarianidi 1972). Central Asians were likely in contact with urban communities across the Iranian Plateau and into the Indus Valley, as indicated by the presence of precious stones and minerals from the Pamir Mountains at Harappa by the third millennium BC (Law 2006). Similar trade networks for lapis lazuli have been traced into Iran and central Asia (Tosi and Piperno 1973). At the start of the second millennium BC, so-called royal burials at Gonur also contained remains of four-wheeled wagons, along with other items interpreted as high-status symbols, such as seals, staffs, and exotic worked stone (Sarianidi 2005:240).

Farther afield, pictorial representations of animals harnessed to wheeled vehicles are also documented in Mesopotamia from the middle of the third millennium $\mathrm{BC}$, albeit illustrated with wild equids rather than cattle as draft animals (Oates 2003). Kohl suggests that the importance of carts in ritual contexts across Eurasia may have helped promote the status of domesticated horses more widely (Kohl 2007:142). The association of political power with chariots and horses is vividly evident in the late Shang dynasty (ca. $1250 \mathrm{BC}$ ) cemeteries of Anyang (Cheng 1960). Elaborately decorated chariots, horse tack, and metal grave assemblages illustrate local stylistic influence while also indexing the influence of interregional institutions of burial and political symbolism drawn from beyond the core of the Shang state (Linduff 2003: 140). Across all these territories, effigies and actual cart remains have been recovered primarily in burial contexts, indicating that wheeled vehicles helped shape the institutional norms concerning status and burial.

The association among wheeled vehicles, burial ritual, horses, and eventually political aggrandizement can be seen as a growing alignment in the institutions of political power 
across a vast territory from the third to the second millennium BC. Around $2300 \mathrm{BC}$, the earliest spoked-wheel chariots are known from burials with ritually dispatched horses at the middle/late Bronze Age site of Sintashta, located in the transUral region (Gening, Zdanovich, and Gening 1992). Burial mounds at Sintashta illustrate a full-blown ideological relationship between chariots, horses, and sociopolitical power in the western steppe region by the turn of the second millennium BC (Anthony 2007:372). Mid-second-millenniumBC rock art images of horse-drawn chariots from the site of Terekty in eastern Kazakhstan also suggest that these commodities could be exploited ideologically, despite a lack of physical evidence (Mar'yashev and Goryachev 1998). Perhaps the cultural capital (knowledge) about chariots allowed detached pastoralist communities to slowly align their political institutions within an expanding ideological currency of chariots and high status.

The examples above suggest that wheeled technology in the form of carts, wagons, and eventually chariots represents a key technology that became increasingly tied (ritually and practically) to high status across Eurasia by the late second millennium BC. The early innovation of wagon and cart technology likely happened along diverse paths in at least a few of these regions, but the technology of chariots and its associations came to resonate as far as central Asia, south Asia, China, and the Near East. The institutional impact of wheeled vehicles was clear. Chariots and the animals attached to them (horses, camels, etc.) had become signs of power and economic importance (Sherratt 2003). These instruments and symbols of power-among other commodities-were fundamental for pastoralists to leverage their local institutional norms concerning political demonstration, burial, and trade among Bronze Age societies of the steppe, China (Falkenhausen 2006), Iran (Hiebert 1998), and beyond (Kenoyer 2004; Lamberg-Karlovsky 2003; Possehl 2002; Potts 2008).

Metallurgy, like wheeled transport, has been the focus of studies that flesh out the details of the broadening patterns of exchange and technological diffusion across Eurasia from the third to the second millennium BC (Linduff 2004; Mei 2003; Peterson 2009; Roberts, Thornton, and Piggott 2009). Growing regional alignment is evident in the shift from the locally conscribed production of copper objects in the fourth and early third millennia BC toward an ever-widening arena of shared bronze technology and design among regional populations from the western steppe to Xinjiang (western China) by the late second millennium (Chernykh 2009; Mei 2009). The growth of metallurgy across a political and social arena ranging from eastern Europe to China, Iran, and the Near East represents a trajectory of institutional relationships that converged across Eurasia in the late Bronze Age yet through different circuitry than did carts and chariots.

Western-steppe metallurgy appears to have stemmed from fifth-millennium-BC copper- and goldworking in eastern Europe (Chernykh 1992). At this time, exchange in metal resources (raw materials and finished products) was regionally circumscribed across western Eurasia and southwest Asia (Thornton 2009). By the early to mid-fourth millennium BC, simple bronze technologies had diffused as far as the steppes north of the Black Sea and east to the trans-Urals (Chernykh 2004), while in the Caucasus, bronze objects found within Maikop burials illustrate a substantial growth of wealth and resource acquisition among pastoralist groups. Kohl suggests that Maikop metallurgy was shaped in part through interactions between western-steppe and Mesopotamian groups (Kohl 2009a).

Around the same time in the eastern steppe, metallurgical consumption among Afanas'ev groups was limited to small decorative copper objects of simple form (Chernykh 1992: 183). These objects were made essentially of pure copper, and their early chronology "precludes any temporal correspondence with the artifacts of the Circumpontic Metallurgical Province" (Chernykh, Kuz'minykh, and Orlovskaya 2004: 20). ${ }^{5}$ The range of objects attributed to the mid-third millennium BC in eastern Eurasia is slightly wider and more elaborate-including knives, awls, nails, and bracelets. Yet the chemical composition of metal artifacts from these "Okunev"type burials are also mostly copper, with only trace elements of antimony, arsenic, lead, and silver (Savinov 1997). This significantly differentiates them from the arsenical copper/ bronze of the third millennium BC in the western steppe.

By the turn of the second millennium BC, a wider arena for the exchange and transmission of bronze objects and technology was emerging between western and eastern Eurasia. Chernykh (2009) has proposed a process of multidirectional diffusion of metallurgical technologies from the late third millennium BC, fueled in part by the need for ore resources, that may have drawn populations into contact beyond their typical geographic ranges. Substantial copper and tin deposits were exploited in the Altai Mountains as well as along the Ili River and in the Dzhungar Basin of Xinjiang (western China; Mei 2009). Ancient mining is also documented from the lower Zerafshan Valley (Parzinger and Boroffka 2003). By the middle of the second millennium BC, numerous shared metallurgical forms extended across most of the Eurasian steppe zone, reaching Europe in the west and China in the east (Linduff 2009).

In much the same way that the cross-pollination of innovations surrounding wheeled vehicles reflects the growth of a shared ideological institution among regional societies by the second millennium $\mathrm{BC}$, the growing economic push for control or acquisition of bronze technology sparked expanding interactive channels across the steppe. This distribution includes the enigmatic Seima-Turbino phenomenon (ca. 1900-1700 BC) as well as more extensive distributions of tin-bronze and lost-wax technology well into the southern reaches of central Asia (Anthony 2009). The widely comparable production and style of bronze knives, axes, and other artifacts across the Eurasian steppe illustrates that the growing

5. This province conforms broadly with the territory defined here as the western steppe region. 


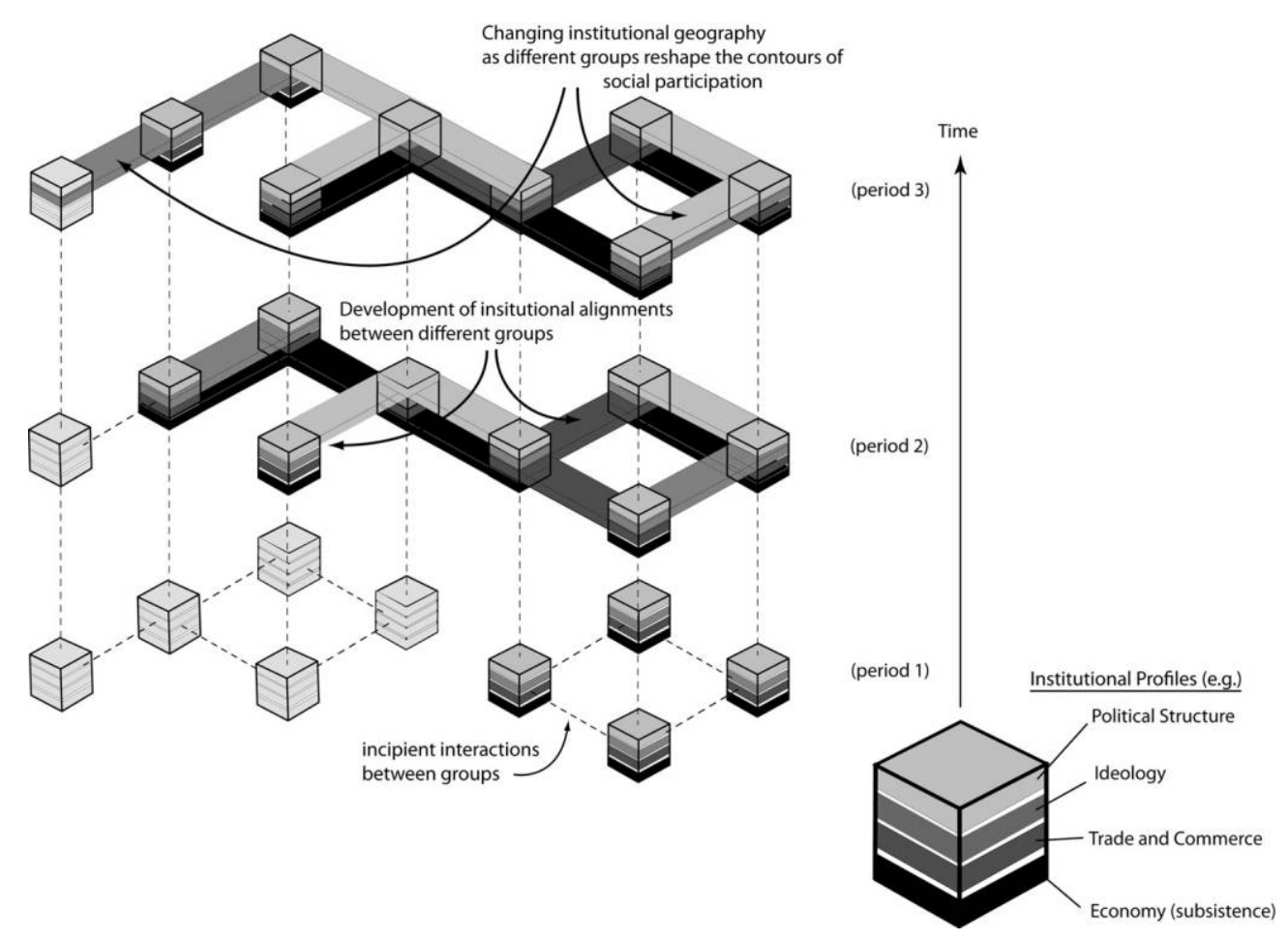

Figure 6. Schematic representation of the dynamic geography of nonuniform institutional alignment. Each cube represents a quasi-autonomous community whose institutional profiles are diversely aligned at a given time and that change through time. A color version of this figure is available in the online edition of Current Anthropology.

importance of metal objects-functionally and symbolically-sparked distinct alignments of social and political institutions during the later part of the second millennium BC among pastoralists of the steppe and with civilizations on the steppe fringe. However, the geography of shared metallurgical institutions reflects a scale and an orientation different from those associated with wheeled vehicles.

Different theories have sought to explain the complex economic, ideological, and material changes that accompanied the various vectors of exchange and interaction evident across Eurasia in the Bronze Age. The traditional cultural-migration theory (above) is based fundamentally on the ethnogenetic correlation between material forms and people (Kuz'mina 1986, 2007). For decades this idea has steered more nuanced models of interaction across Eurasia, such as core-periphery models (Kohl 1987). Now, as we increasingly document the great extent and complicated character of regional ties and material diffusions that shaped Eurasian Bronze Age communities, it is increasingly apparent that a concise theory to explain the variation and similarity is unlikely to surface (Kohl 2008, 2009b). Instead, current archaeology illustrates that regional histories, local environmental pressures, and cultural crosscurrents were sufficiently different across Eurasia. Communities living thousands of kilometers from one another did not generate a consensus of social institutions. In cases where general institutional paradigms did develop, they matured along both strategically formed and unintended channels of diffusion, as outlined above concerning wheeled vehicles and metallurgy in the second millennium BC. To assess the broader influence of Eurasian steppe societies (an analytical unit that should not exist in the first place), we must recognize that the great distribution of similar materials and the associated institutional norms they predicated were shaped by diverse ambitions and punctuated interactions among regional groups.

I have proposed the concept of "nonuniform" complexity to explain how economically and culturally diverse communities came to shape wider-scale institutional movements across Eurasia (Frachetti 2009). This paradigm builds from a definition of institutions common in New Institutional Economics: "the humanly defined constraints that shape human interaction" (North 1990:3). In this sense, organizational structures-such as shared trade parameters, building conventions, ideological symbolism, or even the value or signification of particular technological innovations-demonstrate periodic institutional alignments among participant communities without demanding they be subsumed under a coherent political structure or social identity. 
"Nonuniformity" refers to cases where some institutional forms are homogenized among diverse groups or are mutually reshaped among them for strategic purposes while other institutions remain locally or specifically defined. Thus, for each participant community, the degree of organizational consolidation or fragmentation depends on the degree of cohesion of various institutional structures vis-à-vis their neighbors and the periodic willingness of those communities to adopt or develop similar constraints to their modes of interaction (fig. 6). This structural alignment can be traced through the growing resonance of institutional forces from "specific" to "general" scales.

Specific institutions enfold the guiding principles that shape culturally particular practices within localized social contexts, such as specific taboos or certain practices that constrain behavior among discrete in-groups. For example, in the fourth millennium BC, eastern and western pastoralists were economically different and did not participate in shared spheres of technology and innovation. Thus, we may infer that their social norms concerning herding and metallurgy, as well as their ideological association with innovations such as horse riding or carts, fell under diverse institutional frameworks. Yet as steppe communities increasingly widened their spheres of interaction, some institutions appear to translate over a wider, more general scale. General institutions represent categorically broader social structures that can be integrated into various specific social and cultural systems while indexing more widespread and homogenous norms or constraints. General institutions emerge from a variety of mechanisms, such as long-distance trade parameters, building conventions, and the growth of ideological symbolism. When eastern and western pastoralists of the early third millennium BC are compared, parallel aspects in their burial rites (e.g., body position) might indicate a diffuse stream of ideology circulating between groups. As networks among eastern, central, and western pastoralists extended farther across Eurasia (ca. 2500), we witness increasing alignments in social relationships relating ideological and technological factors. Shortly after central-Eurasian horse herders began to transform their economy toward mixed-herd pastoralism, carts and chariots become widely employed as status symbols, shaping ideological institutions that were ultimately adopted far beyond the steppe periphery.

General institutions, as such, reflect derived or transmitted codes of behavior and ideology that shape common practical behaviors and interactions among participant communities across wider shared arenas. These can also apply to diverse groups who might manipulate them, given their individual motivations or vantage point (Freidel 1983). Specific and general institutions fall along a scalar continuum, making the identifiable transition from one to the other the key to understanding emerging complexity within a diverse social economy. Applying this rubric, we can trace the emergence of broader interactive complexity in Eurasia through time by documenting the transition of institutional indexes from specific to general and from local or regional to interregional.
In the case of the Bronze Age steppe, the transition from locally specific institutional structures to wider-scale general institutions is characterized by nonuniformity because the degree of institutional cohesion among steppe groups in particular areas appears to have been periodically synchronized and organized in some aspects while diverse and at odds in others. A synergy of economic and political interests across Eurasia fostered the transmission of material innovations and forces of ideology, but these institutional alignments did not necessarily draw regional communities into a shared sense of society.

\section{Conclusion}

The development of mobile pastoralism as a specialized socioeconomic strategy across the Eurasian steppe is best understood as a multicentered and regionally diverse process. In the western steppe zone, early mobile pastoralists likely gained access to domesticated animals from neighboring agropastoralists. Yet in many cases, especially in the Caucasus and trans-Caspian regions, the specialized ecological strategies of western steppe pastoralists were developed among hunting groups of the late Eneolithic. Herders of the north-central steppe zone provide the earliest concrete evidence of horse domestication at about $3500 \mathrm{BC}$, but mixed-animal herding was not evident in the early pastoralist economy there until the mid- to late third millennium BC. Meanwhile, societies living throughout a proposed "Inner Asian Mountain Corridor" (IAMC) of the Pamir, Tian Shan, Dzhungar, and Altai ranges represent key agents of the earliest diffusion of sheep and goat pastoralism to inner Asia around 3500 BC. Mountain-adapted groups may have first taken advantage of the domestic animals among their agropastoralist neighbors, such as at Sarazm, in the late fourth millennium BC. Through the inherent variation of seasonal movement throughout the mountains, incipient sheep- and goat-herding economies spread along the IAMC by the late fourth millennium BC. Emerging networks and flexible interactions among mobile pastoralists had a transformative effect on the economy and social organization of the region and set the groundwork for later economic and ideological ties among regional societies within and beyond the steppe.

By the second millennium BC, these incipient regional interactions fostered the spread of new and emerging technologies, cross-fertilized domestic and economic innovations, and ramped-up trade in commodities and raw materials. This growing interactive network promoted new opportunities to extend institutional codes and to capitalize on flexible regional political relationships. For example, quality metallurgy and chariot technology had immediate and transformative impacts among steppe communities by the mid-second millennium BC but also had protracted effects on societies that sought to define unique political economies at the steppe fringe (Possehl 2004). The mobility and geographic extension that were key to the success of steppe pastoralists on an economic level also shaped an array of "nonuniform" institu- 
tional alignments that pushed materials and innovations at unprecedented geographic scales throughout the second millennium BC.

Instead of seeing the expansions of Bronze Age social and economic innovations as resulting from episodic migrations or ecologically induced shifts of populations across Eurasia, I have described a process of growth for regional contexts of social interaction that defined a major revolution in the sociopolitical complexity of Eurasian societies from the third to the first millennium BC (Frachetti 2008, 2009). Such rethinking is timely because new archaeological findings from central Eurasia enable us to explore the intricate interrelationships among regionally conscribed societies whose microeconomy was independently motivated yet whose macroeconomy grew networks over unprecedented scales. Central Eurasia offers vast potential for new archaeological discoveries to illustrate more comprehensibly the confluence of domestic strategies, technology, materials, and ideologies that developed between disparate societies. Albeit still gaining in data exposure and theoretical sophistication, Eurasian steppe archaeology also provides a unique perspective on the catalytic role that mobile pastoralists had in shaping the connections among regional civilizations and in promoting diverse institutional alignments across Eurasia throughout history. The development of nonuniform institutional complexity among Eurasian pastoralists fundamentally illustrates a political and economic structure applicable to societies whose political and territorial scales are inconsistent with common evolutionary or corporate sociopolitical typologies such as chiefdoms, states, or empires yet whose influence on globally scaled economies and institutions was formative.

\section{Acknowledgments}

I am grateful for the insightful comments of C. C. LambergKarlovsky, Philip Kohl, James Mallory, Mark Kenoyer, David Freidel, Michael Harrower, and six anonymous reviewers, who provided detailed and thoughtful critiques of earlier drafts and graciously offered their expertise on how to improve and better organize the argument. I am grateful to Amriddin Berdimuradov and Farhod Maksudov, in Uzbekistan, and Sharof Kurbanov and Yusuf Yakubov, in Tajikistan, for their unparalleled hospitality and education during my research trips to sites and archives in their respective countries. Omissions and errors in data and interpretation are mine. This paper is dedicated to the memory of Professor Gregory L. Possehl (1941-2011).

\section{Comments}

\section{David W. Anthony}

Anthropology Department, Hartwick College, Oneonta, New York 13820, U.S.A. (anthonyd@hartwick.edu). 8 VI 11

The wheat and millet from Begash Ia are important discoveries, because they could mark a possible route through which cultivated grains diffused between China, central Asia/Iran, and the steppes before 2000 BC. But the central thesis of the article, that a specifically eastern-steppe variety of pastoralism based on domesticated sheep and goats with few cattle and no horses diffused northward during the fourth millennium BC from central Asia to the western Altai Mountains, remains unproven if interesting. The southern half of the proposed mountain corridor is defined by just two sites, the agricultural urban outpost at Sarazm in Tajikistan and the possibly agropastoral encampment at Begash in eastern Kazakhstan. They are linked by Frachetti to a distant northern alpine pastoral culture, Afanas'ev (or Afanasievo) in the western Altai, which began in the mid-fourth millennium $\mathrm{BC}$ and ended before 2300-2100 BC, when Begash Ia was first occupied. Begash and Afanas'ev belonged to different eras. That leaves Sarazm and Afanas'ev, 2,200 km apart, to define the proposed IAMC during the fourth and most of the third millennia BC. Sarazm does not show material parallels to Afanas'ev. Exotic combpricked pottery found at Sarazm probably was from local central-Asian Kelteminar desert foragers (Lyonnet 1996:116), not discussed, rather than distant Afanas'ev. Burial poses differed: supine extended or with raised knees in Afanas'ev and contracted on the side at Sarazm. Sarazm used copper and metallurgical techniques distinct from those of Afanas'ev (Chernykh, Kuz'minykh, and Orlovskaya 2004; Isakov et al. 1987). Riverine urban agriculture differed significantly from alpine pastoralism even if both used sheep. Afanas'ev herders had domesticated horses, found in eight cemeteries (Kuz'mina 2008:205) as well as the two settlements in figure 4. Neither Sarazm nor Begash Ia had horses.

In contrast, Afanas'ev exhibited many material parallels with the contemporary western-steppe Repin and Yamnaya cultures. Both had horses. Afanas'ev had more sheep/goats than cattle, and so did some of the most important fourthmillennium-BC western-steppe settlements (Usatovo, Sredni Stog 2, Mikhailovka I, Repin, and Ivanovskaya, none cited here). Ceramic types and decoration, as well as burial poses, were strikingly similar. Both had kurgans covering 1-3 individual graves. Afanas'ev metallurgy was not limited to "small decorative ... objects" but included axes and daggers of specific Yamnaya types (fig. 1.4 of Chernykh, Kuz'minykh, and Orlovskaya 2004). Keyser et al. (2009) did not "uncritically" accept the hypothesis of a western origin of Bronze Age Altaians but tested it and found both maternal and paternal genetic links between the Bronze Age DNA of the western Altai and modern Europeans.

Ecologically, the notion of an IAMC including the Altai is complicated by many animal and plant species of Middle Eastern origin that are limited by the Syr Darya River and by others, such as the Caspian tiger, that ranged no farther north than Lake Balkash in eastern Kazakhstan (Murzaev 1958:426, 431-432). A continuous line of deserts north of the Caspian, Aral, and Balkash lakes separated the northern steppe belt of Kazakhstan and the western Altai from the southern oases of 
central Asia and the Tien Shan, cutting off the northern segment of the proposed IAMC, with the Afanas'ev culture. Wild horses seem not to have ranged south of this desert barrier until humans took them across it about 2000 BC, probably explaining why they were not present in Sarazm or Begash Ia. Afanas'ev horses were not wild; they were introduced to the Altai by Afanas'ev pastoralists and had not appeared in graves of indigenous Kuznetsk-Altai foragers (not discussed) who were buried with elk, fish, fox, and bear teeth and images (Bobrov 1988:35).

The proposed stereotyping of steppe pastoral economies into three geocultural varieties (western cattle-focused, central horse-focused, and eastern sheep-focused) was contradicted by Frachetti himself in wisely warning that all steppe pastoral systems were adapted to local conditions. Sheep generally dominated where conditions were more arid and cattle where pasture was lush. Sheep-dominant sites were widespread in the western steppes (see above), and the cattle-dominant late Bronze Age (LBA) settlement Talapty neighbored sheep-dominant Begash. Cattle and horses were important in easternsteppe pastoralism generally, if not at Begash Ia. LBA (18001200 BC) settlements in eastern Kazakhstan, Frachetti's eastern region, averaged $44.3 \%$ sheep/goats, $38.9 \%$ cattle, and 16.8\% horses (Kuz'mina 1994:208), proportions different from those at Begash and Sarazm. The sites chosen to define the western steppe region also are not representative. In figure 4 , four of the five sites used to define western-steppe pastoralism were seasonal antelope-hunting camps in the north Caspian desert. Dergachev (2007, app. 1) lists three dozen other western-steppe settlements with fauna (some named above). Tripol'ye was not a western-steppe culture but was confined to the rainfall agriculture zone.

Begash Ia is critically important but constitutes a single small candle in a vast dark region, and its affiliations remain unclear. Globular pots with sharply everted rims in Begash Ia seem similar to contemporary Catacomb-culture pots from the western Kalmyk steppes, as at Ergenenskij kurgan 13, so there might be a trace of western steppe influence at Begash Ia; and its cereals could indicate a connection with Sarazm and the south. But its affiliation with a proposed IAMC seems premature, given the dearth of sites available to define such an entity.

\section{A. V. Epimakhov \\ Institute of History and Archaeology, Ural Branch of the Russian Academy of Science, Kommuny Street 68, Chelya- binsk 454000, Russia (eav74@rambler.ru). 23 VIII 11}

The article has an indubitable appeal because it attempts to create a complete picture of processes for the Eurasian steppe in the fourth and third millennia BC. Regional studies, which are very important, are not able to and do not give us the answers to many questions. The Bronze Age of the region under consideration (especially in the second millennium BC) is a period of huge cultural regions and lengthy trans-Eurasian connections whose origins lie in the previous period.

There is no doubt that the key section in the chain of innovation for this area was the adoption of a food-producing economy in the form of complex animal husbandry. The new facts do not fit into the procrustean bed of the traditional model of this process, which supposed only one way of dissemination from the west to the east. I do not deny the role of migrations in the development of cultural similarities and the diffusion of economic, technological, and social innovations, but I think that their directions and forms should have been determined by the proximity of the ecological niche and/ or the direction of relationships that had emerged earlier. For these reasons, the idea of different ways for the animal husbandry movement to move to the east is basically profound.

A more specific matter concerns the classification of certain Eneolithic cultures of the central-Eurasian steppe zone as pastoral. Some specialists disagree with such a characterization of the Botai and the Tersek cultures (e.g., Kosintzev 2006) and suppose that the main model of life support was an appropriating economy. Anyway, there are no paleozoological arguments about horse domestication in this zone. However, the thesis about the various ways animal husbandry was adopted in the steppe area is not weakened by an acceptance of the appropriating nature of the Eneolithic populations' economy (partly synchronous with the Yamnaya and the Afanasievo traditions of the early Bronze Age).

Today, the Yamnaya culture sites of the early Bronze Age are well represented in the trans-Urals, although they tend to be in the foothills and the edge of the forest-steppe zone (Degtyaryova 2010). Early Bronze Age complexes are still rare in the huge area between southern Siberia and the trans-Urals. It is thus difficult to make a choice between versions: traces of migration or contacts. According to our estimates (16 dates), the period of the Afanasievo culture (2920-2460 [4000-2300] cal BC) is not significantly different from the period of the Yamnaya culture.

There are other weaknesses in the chronological interpretations. In some cases, the intervals are based on single dates; in others, the new data allow us to improve the results of summation significantly. The former are exemplified by the Sergeevo- and Balandino-type sites of northern Kazakhstan. The Sintashta type is a different case. A large series of dates has been accumulated, and the combined probabilities give a range of 2040-1730 (2900-1500) cal BC (Epimakhov 2007). In fact, further augmentation of the number of dated samples (Krause et al. 2010) did not affect the final result (2030-1740 [2300-1400] cal BC).

Frachetti has proposed the conception of nonuniform institutional complexity for the characterization of steppepopulation social structures. Similarly, I have concluded that it is impossible to use the existing sociopolitical typology in 
the study of Bronze Age societies of northern Eurasia (third to early first millennium BC; Epimakhov 2009a, 2010). This means that the socioeconomic model invented by the steppe population is independent. Fluctuations of social complexity are connected with the strengthening/weakening of hierarchical structures as well as with the degree of integration of independent societies in the framework of regional and interregional relationships. These factors must have been present in the previous period (fourth to third millennium BC). Thus, the proposed concept can be used in the analysis of a wide range of materials. This article makes a good impression (including demonstrating a good knowledge of the Russian literature), and it allows us to take a fresh look at the existing data.

\section{Bryan K. Hanks and R. C. P. Doonan}

Department of Anthropology, University of Pittsburgh, 3132 WWPH, 230 South Bouquet Street, Pittsburgh, Pennsylvania 15260, U.S.A. (bkh5@pitt.edu)/Department of Archaeology, University of Sheffield, Northgate House, West Street, Sheffield S1 4ET, United Kingdom. 9 VI 11

Michael Frachetti's contribution offers a new perspective on the development and expansion of early pastoralism across central Eurasia and urges scholars to reevaluate traditional models for the multiregional development of mobile pastoralism. In particular, the author offers a well-situated model for the IAMC as a vector for the diffusion of mobile herding. This argument is strengthened by the author's comprehensive regional review, which stresses the diversity of prehistoric steppe pastoralism within the western, central, and eastern steppe zones. These arguments are especially valuable in light of traditional debates over the connection between the Yamnaya culture expansion from the west and the emergence of the Afanesevo culture in the Altai region. It is particularly in the context of this problem that the IAMC model provides a novel way of considering the diffusion of pastoralism not only within central Eurasia but also perhaps into the eastern steppe zone. We especially hope that scholars will weigh in on the latter issue-concerning the emergence and development of pastoralist regimes in northwestern China and Mongolia - and that the author himself will continue to explore this important thesis.

Frachetti also effectively highlights several problems that continue to afflict the archaeology of early steppe pastoralism, namely, the fragmentary nature of archaeological and archaeozoological data, the lack of coherent radiocarbon dating schemes, and the frequent scholarly conflation of steppe communities into "monolithic units" of study. Unfortunately, these problems will continue to stand as a challenge to the development of more nuanced models that account for local and regional change across northern Eurasia, and it must remain the responsibility of scholars working in these regions to work toward overcoming these challenges and to produce more robust data sets for the study of early pastoralism.

While we are generally in agreement with much of what the author asserts in his paper concerning the IAMC and multiregional trajectories of pastoralist development, we question several aspects of his argument connected with the model of "nonuniform institutional complexity." We wholeheartedly agree with the author that the emergence and development of Eurasian steppe pastoralism unfolded along unique historically situated trajectories of development and that they thus require, perhaps, novel approaches to model building. Therefore, we applaud the author's efforts in using New Institutional Economics (North 1990) as a different perspective on steppe sociopolitical and economic interaction. This is especially the case when setting this theoretical approach within a broader heuristic light, yet we remain unconvinced by the current productivity of the approach for considering specific regional and microregional developments and social, political, and technological change. Eurasian steppe archaeology has never suffered from a lack of large-scale models and grand narratives. Yet we desire to see the application of models that actually help to structure and guide field research and the collection of empirical data that can validate one model as more effective and productive than another. Does nonuniform institutional complexity offer such a framework? Future scholarship will be the judge of this; however, we offer some brief thoughts on the merit of this model specifically in the context of the author's discussion of trade, exchange, and prestige innovations.

While broad analyses of archaeological evidence can convincingly indicate a general development toward greater interaction and trade by the late Bronze Age across Eurasia, we believe that the resulting syntheses often overshadow important regional changes that when considered alone might counter or at least temper such grand narratives. For example, in the southern Urals, chariot technology emerged by 2100 $\mathrm{BC}$, yet it was already waning by the time it appears to have "diffused" south and eastward into Kazakhstan by the midsecond millennium BC, and it had disappeared in the southern Urals centuries before it gathered importance in Anyang, China, around 1250 BC. We would ask, what does such discontinuous transmission really tell us about long-distance political interactions? Turning to metal production, similar issues become apparent. While categories of mobile material culture might be shared over significant distances, this tells us little about the range of practices that communities used to realize access to such commodity resources. Academic interest in the apparent similarities among artifact types may well obscure a diversity of production traditions in place across a broad region not just in terms of technical knowledge and resource perception but critically in terms of how production was organized socially, spatially, and temporally. If political establishments align themselves through shared yet 
restricted elements of material culture, then perhaps it is the localized strategies by which individual communities secured their right to participate in this arena that demand our attention. From our position, then, we welcome the author's paper but hope that it directs future research toward more productive regional studies rather than offering yet another grand narrative that does little to highlight variation in social and technological practice.

\section{Nikolay N. Kradin}

Institute of History, Archaeology and Ethnology, Far East Branch of the Russian Academy of Sciences, and Far Eastern Federal University, Vladivostok, Russia (kradin@mail .ru). 4 VI 11

For a long time, the question of the political complexity of pastoral nomads' societies has disturbed anthropologists and archaeologists. In Soviet anthropology, a boisterous discussion of "nomadic feudalism" has gone on for more than half a century (Gellner 1988; Khazanov 1984; Kradin 2002). In the past few years, these problems have acquired a new meaning in postevolutionist, post-Marxist, and postmodernist contexts (Barfield 2001; Bold 2001; Di Cosmo 2003; Golden 2001, 2003; Honeychurch and Amartuvshin 2006; Kradin, Bondarenko, and Barfield 2003; Kradin and Skrynnikova 2006, 2009; Rogers 2007; Sneath 2007). However, a significant part of these debates concerns the pastoral nomads of the ancient world and the Middle Ages. The contributions of Michael D. Frachetti and other scholars consist in the fact that they attracted attention to pastoral societies in prehistory (e.g., Anthony 2007; Hanks and Linduff 2009; Kohl 2007; Koryakova 2002; Koryakova and Epimakhov 2007).

In Frachetti's paper, the important multilinearity problem of the Bronze Age middle-scale societies' forms is set. This concept was developed in a number of the previous publications (e.g., Frachetti 2008, 2009). In the paper presented here, the conclusions are fully formulated. Many of Frachetti's ideas, especially those concerning regional differences in prehistoric pastoralism in western and eastern Eurasia, are of interest to specialists. We should not think that nomadic pastoralism has not changed in the course of many centuries. It has undergone a continual process of changes and transformation under the action of natural factors, internal dynamics, and the effect of neighboring cultures and civilizations. I agree in full with the basic conclusion of nonuniform institutional complexity in the Bronze Age of Eurasia.

Unfortunately, we are insufficiently aware of the political formations in prehistoric pastoral cultures. Reconstructions of social systems in nomadic archaeology are based more often on free interpretations than on strict facts. On this point, the Celts have been examined in greater detail than have the pastoral cultures of Eurasia, but archaeologists still argue about whether their political system was a heterarchy, a chiefdom, or a state (Arnold and Gibson 1995). Frachetti shows perfectly the differences in economics, but unfortunately he only approaches the question of variability in political complexity. This is a task for his further investigations. We hope that he will soon present the results of his interpretations.

However, one can say at this time that the concept of nonuniform institutional complexity fits well with other theories of sociopolitical complexity: heterarchy and hierarchy or network and corporate strategies (Bondarenko 2007; Grinin et al. 2004; Haas 2001; Price and Feinman 2010). All of these concepts are good tools for insight into the complexity of pastoral polities of the Eurasian Bronze Age. A great number of combinations of heterarchic and hierarchic polities was possible among nomads. At the lowest level, the nomads could be structured into the heterarchic chieftainship or into the hierarchic chiefdom. In turn, the simple chiefdoms could be integrated into complex chiefdoms or a heterarchic confederation of chiefdoms. The Khitans confederation of eight polities in the first millennium AD in Manchuria can serve as an example of the latter. All of these structures were as unsteady as the steppe степное ("tumbleweed") and could at all times change both in the number of component segments and in the character of the internal relations.

The heterarchy-hierarchy dichotomy often depended on different factors, including individual characters of political leaders (Blanton and Fargher 2008). For example, the complex chiefdom hierarchy could be developed in the presence of a successful charismatic chief. After his death, it could be transformed into a heterarchic confederation of chieftainships.

Unfortunately, Frachetti does not touch on the Mongolian steppes in his paper. The Eurasian east appears as a periphery of the steppe corridor. However, this region plays such a significant role that it is worthy of notice. In fact, it contains very large cultural areas that are comparable in size with nomadic empires: the khirigsuur culture and the slab-burials culture. We do not know whether they were heterarchic polities or complex chiefdoms. In the slab graves of different sizes in the East Baikal area, for example, different categories of artifacts were found. According to Tsybiktarov's (1998:7378) calculations, there is a correlation between the sizes of the graves (burials) and the types of finds. Implements were present in $54.5 \%$ of slabs with dimensions of $2 \times 3 \mathrm{~m}$, while arms were found in $48 \%$ of slab graves (burials) of $4 \times 5 \mathrm{~m}$. Also, $46.6 \%$ of graves (burials) with dimensions of $4 \times 5 \mathrm{~m}$ are characterized by the presence of prestige goods. The smallest slab graves have no inventory. There is a certain correlation between such groups of artifacts as harnesses and furnishings and prestige goods. Hence, one can draw a conclusion of the presence in the society of three or four open status groups. However, the question of heterarchy-hierarchy in the culture of slab burials remains unresolved.

Frachetti's conclusions seem to be very significant for understanding prehistoric pastoral societies. He has taken an 
important step in the right direction. It is now necessary to move farther in this direction and to continue broad crosscultural studies in the Eurasian arid zones.

\section{C. Lamberg-Karlovsky}

Peabody Museum, Harvard University, 11 Divinity Avenue, Cambridge, Massachusetts 02138, U.S.A. (karlovsk@fas .harvard.edu). $14 \mathrm{~V} 11$

Since the collapse of the USSR, the archaeology of Eurasia, that vast landscape stretching from southern Russia to Siberia, has become something of an archaeological growth industry. Several nations participate in productive research programs that have dramatically altered our understanding. Among the most innovative work, offering both new excavated data and theoretical perspectives, is Frachetti's (Frachetti 2008, 2009). Wedding landscape archaeology, creative applications of GPS, and archaeological excavations, he has transformed our way of both looking and thinking about Eurasia. Previous approaches, in which large-scale migrations moved from west to east and then back from east to west, are advisedly ignored, while we are mercifully spared speculative mention of Aryan ethnicity and Indo-Iranian language that often dominates the discussion of Eurasian cultures (Anthony 2007; Kuz'mina 2007).

The author captures the excitement regarding the new database and the ensuing theoretical debates involving the origin and diversity of pastoral nomadism and their interaction with sedentary communities. His essay offers us what might be called "the new synthesis" involving the following points.

1. Pastoral nomads inhabiting this vast region are not only at the "physical 'center' of our conceptual map" but can be divided into significant subregions of cultural diversity and regional interaction. Cultural diversity replaces the previous singularity of the Afanas'ev and the "Andronovo cultural community," while the "Yamnaya" culture "illustrates a transition rooted in strategic responses to particular ecological conditions on the part of local populations." The concentration on environment and local strategies of adaptation and interaction all emphasize cultural diversity within distinctive environmental settings.

2. The traditional model of migration and diffusion obscures the important socioeconomic distinctions that the author introduces within the cultural diversity of the western, central, and eastern regions of the steppe. The analysis of this zonal diversity is a significant advance in our understanding of Eurasian cultural adaptation, interaction, and complexity.

3. The author offers a theoretical innovation in introducing the concept of "institutional nonuniformity." The concept is meant to "explain" the near-universal presence of institutional categories of wide distribution, such as burial patterns, horse burial, and the use of domesticates as burial offerings from institutions of local and specific nature. The uniform im- portance of the horse, wagons, and patterns of burial on the steppe were previously sufficient to construct a cultural singularity over the steppes, that is, Aryan-speaking Indo-Iranians. The concept of "noninstitutional structures" attempts to move us away from such simplified perspectives.

4. Central to the author's thesis is the importance of the IAMC. This route linked the central Asian world, via the Pamir-Tianshan mountain ranges, with the Eurasian steppes. It is, in fact, a well-known route. It was the path taken by Marco Polo and was much discussed in the travel literature of the nineteenth century (Lansdell 1885; Vambery 1873). The well-known military explorer Colonel Sir G. J. Younghusband's book The Story of the Guides (1908) offers a vivid description of the native guides who directed foreign personnel involved in the "Great Game" of colonial domination played by Great Britain and Russia through the various routes of what Frachetti calls the IAMC.

Frachetti points to the interaction that tied the earliest agricultural settlement of Sarazm in Tadjikistan to the site of Begash in Kazakhstan via the IAMC. Sarazm, in the Zeravshan Valley adjacent to the Pamir Mountains, is well known for its rich mineral deposits. The presence of the Yamnaya and Afanas'ev cultures at the site of Jukov (Avanessova and Dzhurakulova 2008) and a burial containing materials of both the Bactria-Margiana Archaeological Complex (BMAC) and steppe cultures (Bobomulloev 1999) in the Zeravshan Valley are further evidence for the IAMC channel of interaction between the steppes and central Asia.

Frachetti avoids the issue of whether pastoral nomads formed states and, for that matter, any issue pertaining to their tribal, chiefly, ranked, or stratified social constructions. For that one must turn to Khazanov (1994) or more recently Kradin (2008:121), who concludes that the pastoral nomads of Eurasia formed a "super complex chiefdom." It is perhaps wise of Frachetti to avoid these neoevolutionary typologies.

The interaction of the steppe pastoral nomads with the sedentary cultures of central Asia, the BMAC, is well documented (Gubaev, Koshelenko, and Tosi 1998; Salvatori, Tosi, and Cerasetti 2008), while to the east the cultural influence of the "Andronovo" pastoral nomads in Xinjiang is also noted (Mei and Shell 1999). While the above remnants of cultural interaction are well documented, Frachetti expands the influence of the steppe pastoral nomads to the Indus Valley, the Iranian Plateau, and "perhaps as far as Mesopotamia." Such influence, however, is unlikely to have been direct. Not a single artifact of the pastoral nomads of the steppes has been found in the above regions.

There can be no doubt that channels of trade, resource acquisition, and a chaining sequence of interaction brought East and West into contact by the middle of the second millennium BC. We owe a debt of gratitude to Frachetti and a handful of his contemporaries for elucidating the pastoral nomads of Eurasia as major players in the evolution of Old World cultural complexity. 


\section{Sandra L. Olsen}

Carnegie Museum of Natural History, O’Neil Research Center, 5800 Baum Boulevard, Pittsburgh, Pennsylvania 15206, U.S.A. (olsens@carnegiemnh.org). 24 VI 11

Frachetti presents a constructive synopsis of the current knowledge of the development of mobile pastoralism in the Eurasian steppes while providing his own interpretation of the complexities of local adaptations and cultural identities versus broader shared attributes and exchange. Drawing on a wide range of data, he provides reasonable explanations to recreate the ancient dynamics of the region.

For decades, archaeologists have been struck by the conspicuous similarities of steppe cultures in the Bronze Age. Recently, however, examples of more intensive research with a defined regional focus are elucidating unique characteristics associated with local environs (Chang et al. 2003; Frachetti 2008; Olsen et al. 2006). We are only just beginning to comprehend the heterogeneous nature of steppe economies, with each group utilizing available resources, both domestic and wild, as appropriate for the ecology of its own homeland.

Prehistorians today are trending away from the previous tendency of glossing over cultural distinctions and connecting widely spaced dots of data. The Andronovo cultural community is now being scrutinized at high magnification to tease out internal variations, both temporally and spatially (Panyushkina et al. 2008). There are still many hurdles to overcome, however, to improve our understanding of both local events and the interactions that transpired across this vast landscape.

Given that much is riding on the utilization of wild flora and fauna and the adoption of domestic plants and animals, there is an immediate and urgent need to accelerate the collection and analysis of botanical and faunal remains from sites. Theories centered on pastoralism must consider how individual groups supplemented their "larder on the hoof" with hunting, gathering, or, at times, agriculture. More paleoclimatic data must also be obtained so that global fluctuations and local conditions can be reconstructed. While there have been a few exceptional studies of these tightly correlated subjects in recent years, it is an enormous challenge to fill in all the gaps across the Eurasian steppes.

The weakest area of our knowledge is the Neolithic period, which immediately precedes or in some areas introduces pastoralism. Unlike the Near East, for which there is ample information, much less is known about how the foundation was laid for the formation of herding societies in the steppes. An example that Frachetti touches on is the Atbasar culture of north-central Kazakhstan (Kislenko and Tatarintseva 1999). The ephemeral nature of their camps and the shallowness of their sites mean that there is poor preservation of faunal material and even fewer data on plant utilization. The similarities between the ceramics of the Copper Age Botai culture and those of the Atbasar allow for the possibility that one grew out of the other. If so, then the Botai rapidly shifted to an extreme focus on herding domestic horses and living in large, permanent villages with no indication of a gradual transition (Olsen 2006a, 2006b; Olsen et al. 2006). While the Botai culture has the earliest confirmed evidence of horse pastoralism to date, it is feasible that they received fully domestic herds from a neighboring region yet to be determined. The intermediate stage of hunter/small-scale pastoralist is more difficult to identify than the full-blown equocentric economy of the Botai herders. Kotova (2003) offers the most tantalizing hints in the Ukrainian Neolithic. One of the most difficult obstacles for pinpointing the inception of horse domestication remains the lack of sufficient remains of wild progenitors to establish morphological criteria for distinguishing them from early domesticated horses.

Our work on the Botai has demonstrated that most, if not all, of the horses they exploited were domesticated. The evidence includes mare's milk in pottery (Outram et al. 2009, 2011), corrals, a fauna assemblage consisting of $90 \%-99 \%$ horse remains, heavy butchering on horse bones, significant ritual horse sacrifices (Olsen 2006a, 2006b, 2008), and an abundance of thong-smoothers for the probable manufacture of control devices for horses (Olsen 2001). Weighing heavily in the argument for Botai horse herding has to be the size of their villages, from 44 to 160 or more houses (Olsen et al. 2006). It is difficult to conceive of a sedentary population of between 400 and 1,000 people per settlement surviving long by hunting only wild horses obtained from a territory small enough to be covered on foot. Yet despite the overwhelming evidence that has been amassed for horse herding at Botai, there are still those who resist acceptance of these data as proof. With such a lack of consensus in the field coupled with large voids in our knowledge in many regions and time periods, much work remains to be done before we can adequately substantiate general theories about Eurasian steppe pastoralism.

\section{T. Potts}

Department of Archaeology, University of Sydney, New South Wales 2006, Australia (daniel.potts@sydney.edu.au). 28 VII 11

This is an impressive, wide-ranging paper that appears to me to be largely successful in sketching the regional distinctions between various ancient central and Eurasian societies and in describing the IAMC. It is consciously theoretical, and to that extent it makes many sweeping assertions without providing a huge amount of data to back them up. This is not to imply that the paper lacks data; it is just that it covers so many issues that it would be impossible in anything shorter than a book to fully document all of the points made. As I read, I 
found myself in agreement with many of the assertions, but certainly, as the saying goes, "the devil is in the details," and I found myself wishing for more of those details even where I was in agreement with the author, perhaps particularly where I was in agreement, because evidence kept coming to mind that would both strengthen and complicate his arguments.

With respect to metallurgy, we are left craving more insights into how metal acquisition and use affected the societies of greatest interest to the author. Although Parzinger and Boroffka (2003) and Alimov et al. (1998) are cited, nothing is really said about tin, though its extraction was clearly important in the region. Similarly, the whole topic of wheeled transport is treated fleetingly, leaving the reader craving more detail. Some of the most exciting evidence of wheeled transport is now available in the form of directly dated (through dendrochronology) wooden wheels from Yamnaya-period graves at Sugokleja in the Ukraine (Nikolova and Kaiser 2009: 235-237), and although the Yamnaya material is discussed, I longed to see a more intensive engagement with the arguments made by Anthony and others on the subject of Yamnaya movements from the west to Siberia and Mongolia. The entire study of wheeled transport has been moving ahead by leaps and bounds in recent years through the work of scholars such as Boroffka (1998), Teufer (1999), Raulwing (2000), and Burmeister (2010). This theme is treated, but so much more could be said, and the relationship of wheeled transport on the Eurasian steppe with developments in the Near East, though often alluded to, is far from clear. Finally, although the author fully acknowledges the importance of Sarazm, the very complex set of relationships that Sarazm sustained with areas to the south is not really addressed. The well-dated assemblage of imported ceramics recovered there, with clear parallels at sites in northeastern Iran (Tepe Hissar, Tureng Tepe, Shah Tepe), Afghanistan (Mundigak), and Baluchistan (Bampur), has never been adequately explained and undoubtedly complicates our understanding of what was going on in the late fourth and early third millennia BC (Besenval and Isakov 1989). It would be wonderful to read what the author thinks about this material.

Knitting together the different bits of the Old World in a grand schema has been going on for a long time and certainly did not begin with V. G. Childe. Doing this successfully is a tall order, as many scholars have found out, and apart from pointing to finished goods and raw materials that certainly circulated and some languages or linguistic features, scholars remain to a large extent ignorant of the human actors involved. Frachetti's paper continues in this vein, albeit at a general level. As Oliver Twist once said, "Please Sir, I want some more." If this paper is a prolegomenon to a full-blown book on the subject, then we all have something exciting to look forward to.

\section{J. Daniel Rogers}

Department of Anthropology, NHB 112, National Museum of Natural History, Smithsonian Institution, Washington, DC 20560, U.S.A. (rogersd@si.edu). 5 VI 11

It is completely common and perhaps even normal for a discipline's concepts and theories to become so well rooted that work proceeds in shady comfort with no reason to venture out into the hot sun. As normal as this may be, anthropology does seem to be one of those fields in which a tendency for self-reflection also serves to uproot ideas that have become too comfortable. For western and central Asia, the favored archaeological explanation for major changes was and is migration. Parallel to this is the idea that major innovations had a single point of origin and a discernible path of diffusion. Further imbedded in this cluster of interpretations is the explanation for emergent ethnic differences and broad cultural changes, such as the development of political hierarchies in the Bronze Age (3500-1200 BC; Hanks 2010) and later periods. For the Bronze Age, the study of a vast number of kurgans (burial mounds) has resulted in a densely packed ancient landscape of "archaeological cultures," often named and defined on the basis of less-than-distinctive characteristics (Kohl 2007). The brute-force solution of always excavating more data has resulted in a partitioned past linked together in typological ways. Many of these archaeological cultures are grouped into the Andronovo cultural community. The characteristics of the different cultures within the community have been conceived as a stage in the evolution of later states and empires.

Frachetti's article links the information acquired from the past 30 years of excavations with an emerging theoretical climate that is challenging archaeologists to explore the dynamics of interaction while recognizing the complexities of variability in the material record. As it turns out, there is ample evidence to challenge both linear and geographically uniform processes when it comes to major cultural changes in the Bronze Age. Because Frachetti does give a reasonably detailed treatment of the archaeological evidence, there will be plenty of room for debate. In whatever way these details may eventually work out, Frachetti outlines for the archaeological community some concepts that move the discussion in a new direction while maintaining a strong empirical grounding. The author is actively presenting new archaeological approaches to western and central Asia and has already contributed a host of new ideas to what has in the past been a predictable rendering of the culture history of the region, with some important exceptions. Three concepts presented by Frachetti are of particular note: (1) the idea that there are multiple distinct trajectories for the development of mobile pastoralism in the western, central, and eastern regions, (2) the concept of nonuniform institutional alignment as an explanation for variability, and (3) interactions along the IAMC as a previously unrecognized source of interactions. 
The differences between the west, central, and eastern regions reflect the emergence of variability followed by a long history of culture contact interactions that occurred in nonuniform ways - sometimes energized by power differentials but also occurring as trade or conflict between local peer communities. It makes sense that each of these local communities/regions had somewhat different institutions, resources, and strategies. It may also be true that at certain junctures, powerful external forces facilitated a merging of traditions and a kind of uniformity where none had existed before. Presumably, under conditions of broad-based political systems, institutional alignments increased, but there were always edges and others. One also wonders whether archaeologically discernible differences exist in the relative centrality of official and unofficial sources of power under conditions of high institutional nonuniformity.

One of the reasons this paper makes a real contribution is because the ancient societies at the heart of this study do provide alternative cultural trajectories that built on a vast cultural geography combined with mobility of place. These cultural trajectories provide a much-needed wake-up call for how we understand the entire emergence and development of "civilization," or more appropriately, early states and empires. Current theory is almost exclusively envisioned on the basis of sedentary agricultural societies. However, it is becoming harder to brush the pastoralists (nomads) to the margins. For instance, whether or not ancient China came to view the steppe of inner Asia as marginal and full of barbarians, the region was, in fact, the scene of innovations and grand events that matter on a very large scale.

No archaeologist would argue that the past is easy to interpret. This study is welcome for providing both new conceptual tools for envisioning emerging complexities and a much-needed reality check. A fair amount of squinting will take place as the shade recedes.

\section{Natalia Shishlina}

State Historical Museum, Red Square 1, Moscow 109012, Russia (nshishlina@mail.ru).1 VI 11

The vast area of the Eurasian steppe is divided by Frachetti into three major zones whose populations, as the author believes, developed a new type of economy. Such broad synthesis enables the author to put forward a theoretical hypothesis according to which mobile pastoralism originated through interaction of elements such as diverse regional innovations, technologies, and ideologies. This led to the development of specific "nonuniform" institutional political alignments. Therefore, this paper is an attempt to look at an old issue from a different angle. The proposed theoretical model based on the general analyses of archaeological data has its strong and weak points.

Eurasian pastoralism was an absolutely new phenomenon.
It was a specific adaptive system with very peculiar components, including environment, domesticated and wild animals and plants, and settlements and dwelling; the technological base; and social relationships and ideology. So, the question is when, how, and where this happened.

The first question is, what are the archaeological markers of pastoralism? Such markers are very difficult to identify when we deal with archaeological data. The seasonal use of pastures and water resources, dismountable and portable dwellings, and food-acquisition and exchange systems may be identified through application of new approaches. Frachetti adds other supplementary resources exploited (agriculture, mining, and crafts). If we look at the three proposed models, some of them do not fit these characteristics. The Botay model of the central steppe is distinguished from other models. The economy of the Botay population was based on horse hunting and subsequent horse raising. But from the mobile pastoral perspective, they led a sedentary life, did not raise other domesticates (including any plants), and went fishing. The Botay Eneolithic economy was a very specific form that differed from other regional pastoral economies, which were characterized by short-range sheep and cattle herding in the west and vertically transhumant sheep/goat raising in the east.

The same might be said about the examples given for the western steppes. Small communities that occupied different environmental zones of this vast area were not all pastoral mobile groups. The economy of the Volga-Ural-Don population was based on sheep, cattle, and horse raising, use of dismountable dwellings, seasonal movement, and full exploitation of all wild food resources without any domesticates, including a large amount of aquatic components. There is no evidence of the consumption of domesticated plants. Isotope and ethnobotanic data confirm such statements. The population living in this part of the western steppe was strongly linked with the "Caucasus corridor." Innovations were brought through this corridor by population movements and developed further on the steppe. The same trajectory appears to have been used in the IAMC in the east. The Black Sea coastline area supported semimobile herding combined with possible small-scale agriculture, fishing, and gathering, and it provided links with the settled population in the western areas.

The second question is, where can we locate the earliest pastoralists? Through the identification of archaeological markers of mobility, seasonality, and special type of diet, we may say that during the Bronze Age some steppe groups located between the Don and Volga and the Irtysh and Yenisei rivers gradually shifted toward a specific, mobile mode of life. The population in the arid steppe zones of the north Caucasus, a more humid area of the Black Sea coastline, and the Botay area seem to have been more settled, at least until the mid-third millennium BC, and became mobile especially after the heavy draught occurred at 2300-2200 cal BC.

The third question is, when did fully mobile exploitation of the open steppe begin in Eurasia? ${ }^{14} \mathrm{C}$ chronology based on human bones demonstrates that a lot of dates of human 
collagen show the apparent age because of the reservoir effect. Most ${ }^{14} \mathrm{C}$ dates of human bones of the Bronze Age cultures are older than expected. Stable-isotope ratios of the humanbone collagen reflect a freshwater-resources diet. Other effects, such as the effect of old wood, should also be accepted. That is why the combined chronology of cultures analyzed by Frachetti should be revised as well. ${ }^{14} \mathrm{C}$ chronology of the Afanasievo culture is based on the human-bone dates. As the author has shown, the population of this culture was located along rivers, and fishing was a part of their economy. It is assumed that the old age of this culture, which is considered by the author to be the earliest among the mobile pastoral Eurasian cultures, is not correct. It is evident that the exploitation of all food resources, including freshwater resources, should be considered when we look at the chronology based on human bones. The ${ }^{14} \mathrm{C}$ dates of terrestrial samples strongly point to the period around $3000 \mathrm{cal} \mathrm{BC}$ as the beginning of fully pastoral adaptation across the entire Eurasian steppe. Before 3000 BC, the Eurasian population had just started to use some mobile economy elements.

\section{Reply}

I am grateful to each of the commentators for their insightful and compelling comments on my paper. I was excited to see that many were receptive to my arguments, and I hope to sufficiently contextualize some areas of debate that remain unresolved. In writing this article I tried to approach the archaeology of Eurasia with fresh eyes. I aimed to situate the vast extant array of archaeological materials in light of the newly documented sites and chronologies that are starting to chip apart the (aptly described) "procrustean bed of the traditional model." I expect that I fell short in some regards because so many aspects of the current data set remain fragmentary and heavily laden with canonical interpretation, yet I sought to free the archaeological corpus from its paradigmatic chains and introduce a new perspective that somehow leaps toward a new synthesis. This endeavor inevitably translates into hands-on analysis. So, in addition to bringing the past decade's research into the conversation, I spent the better part of 2008-2009 traveling to various regions of central Asia on a material and intellectual quest. I handled the contentiously provenienced material from Sarazm in Tajikistan; I spoke with transcendent experts of the "Soviet school," such as Nona Avanessova in Samarkand, and tried to absorbed their extensive skill for distinguishing nuanced pottery types (Avanessova sees considerable differences between Yamnaya and Afanas'ev ceramics; personal communication, 2011); I dug through the unpublished archives in institutes across the region and visited unpublished (and some unstudied) sites in Tajikistan, Kyrgyzstan, and Uzbeksitan; I spent long hours drinking - tea —with archaeologists who worked in the Altai and central and northern Kazakhstan and pressed archaeologists working beyond Eurasia, in China and southwest Asia, for new information and unpublished data. Throughout this reconnaissance, I found myself struck by the great diversity within the material that has been studied collectively within the scope of prehistoric "Eurasian archaeology," and I was boggled by the fact that it was ever envisioned through the rubric of single macroregional sociocultural enterprise. As a number of commentators rightly note, we are flush with global models that gloss over so much of this regional detail. With so much diverse material to digest and so much more detail that never makes it into the grand narratives, my project to "let the archaeology show me the light" seemed increasingly daunting.

Alas, the early drafts of this article were upward of 30,000 words, which were later pruned substantially. Of course, while digesting these data one quickly falls into complicated "rabbit holes," exploring topics such as how distinct the "Repin culture" is from the "Yamnaya culture" or how many stylistic indicators it takes to justify "cultural" cohesion between distant regional groups. Although I agree with many of the commentators that theory must build from archaeological details in regional context, I was unsatisfied by current theoretical explanations that boxed in regional diversity and then strung those boxes into chronological sequences. In fact, the archaeological materials I was handling exposed an unexplored social morphology, an economic and political system that was, as Epimakhov rightly notes, "independent" from those we know in the Near East or China. With reconnoitered evidence I tried to illustrate this uniquely shaped multiscalar system, in which some institutional forces operated locally, others regionally, and still others macroregionally. Adeptly noted by Lamberg-Karlovsky, I explicitly tended away from the material-cultural/typological approach, highlighting instead the "environment and local strategies of adaptation and interaction [that] emphasize cultural diversity within distinctive environmental settings."

The data underlying my arguments reveal a persistent paradox, because no matter how we parse the typological and chronological nuances, the populations across Eurasia were, on the one hand, practically and socially diverse region to region. On the other hand, they were institutionally and materially interrelated. In order to move beyond the paradigm of the "Andronovo culture," I picked a complex rabbit holethe emergence of Eurasian pastoralism-and dived in wideeyed. Although cognizant of the complex ontology of mobile pastoralism (duly noted by Shishlina), I sought to track a simple material index—something tangible that needed "less" interpretation. So I surveyed the published faunal record to get at the basics of Eurasian societies: what were these folks eating, and how did it affect their social ecology? Simplicity averted, I had to find comparable data sets, which means deciphering which of the Soviet reports were listing something equivalent to "number of identified specimens" (rather than MNI, because with small data sets MNI can be highly mis- 
leading). Compiling a representative data set from across the Eurasian steppe, I observed a compelling trend within my geographic-information-system analysis of regional faunal distributions: western-Eurasian herders relied more on cattle, central and northern communities focused more on horses, and eastern-steppe pastoralists more heavily exploited sheep (especially in the fourth and third millennia BC). As one would expect, there are "whiskers" on any statistical data, and each region has its own internal diversity. Nevertheless, the pattern is there.

In his commentary, Anthony suggests that I may have missed some sites (possibly by excluding MNI reports) and basically argues that my observed pattern does not hold up to scrutiny. By way of avoiding another rabbit hole here, I can dutifully report that in the time since I submitted my paper and the time of writing this reply, someone else has provided a corollary statistical analysis of the herding economies of the steppe, which-in addition to my analysisshould put Anthony's concerns to rest. Bendrey's recent article (2011) illustrates in robust fashion effectively the same pattern I present above in his thorough statistical analysis of Eurasian Bronze Age faunal data. He states that

the Bronze Age data reveals a west-east trend in the representation of cattle in the archaeological record, with cattle representation highest in the western steppe and lowest in south-east Kazakhstan (Figures 2 and 3A). . . The proportions of sheep/goat bones at Bronze Age sites appears to mirror the situation seen in cattle, with the lowest numbers seen in the western steppes and the highest in south-east Kazakhstan (Figure 3B). (Bendrey 2011:9)

Shishlina's commentary provides an important nuance to the point about regionally different characteristics of mobile pastoralism, especially concerning the diversity of pastoralist systems of the western steppe zone. She illustrates in greater detail the variability that exists there and proposes a "Caucasus corridor," which she thinks transformed western steppe economies toward specialized pastoralism, much like the IAMC in the east. I agree with Shishlina in her assessment, and I would love to see whether a "nonuniform" institutional perspective can be applied in more detail to the Caucasian region.

A number of commentators added nuance to my discussion of north-central steppe "pastoralism" in the mid-fourth millennium BC. Shishlina, Epimakov, and Olsen each present a slightly different assessment of the practical economy in this territory ca. 3500 BC. Epimakhov notes that many view the Botai economy as an "appropriating" strategy that thus may not really fit within a model of pastoralism at all. Whether that economy was pastoralist or not, he does not see this fact as weakening the distinction of the central steppe from either the west or the east, but the issue clearly defines an ongoing debate. Shishlina and Olsen both remark that the occupants of Botai-type sites were likely sedentary, which further distinguishes them from western and eastern pastoralists. Although the Botai societies were sedentary, Olsen nonetheless views them as specialized herders nearly exclusively devoting their time to raising horses.

Olsen's stance is rooted in what I see as solid evidence, because the milk lipid residues and corralling she has documented evince that a significant proportion of the horses at Botai were being managed, corralled, and milked (Olsen 2006a; Outram et al. 2009). Addressing Shishlina's three pastoralist queries is relevant here, and I agree that defining what "pastoralism" means in the case of Botai demands different criteria from the eastern or western steppe contexts. Olsen rightly identifies the need to trace the Neolithic evidence for this sudden shift in economy from decidedly hunting strategies to a unique form of sedentary herding. However, what I find important from this ongoing debate is that in spite of the diverse interpretations of Botai, all three of these specialists agree that the economy of the central-Eurasian steppe represents an adaptation different from that of contemporaneous eastern and western steppe communities. Domesticated horses are unquestionably important to the development of steppe pastoralism but may not be the primary ontogenous force for the whole region. Western, central, and eastern forms of pastoralism emerged along unique trajectories, which makes it very difficult to believe that they align along some linear diffusionary path, a point also well stated by Rogers in his commentary. The ecologies of the western, north-central, and eastern steppe regions are different, and thus it is not surprising that pastoralist strategies are different as well.

Anthony argues that the ecology along the proposed IAMC is divided by substantial deserts, which among other things prevented Eurasian tigers from ranging north beyond Lake Balkhash. Thus, he questions the IAMC. Tigers are not grazers and thus do not speak to the ecology in question, which is one of grassy upland pastures and ungulates maintained by humans. Considering this, the vertical ecology of mountain steppe and meadow pastures across the proposed IAMC is comparable (minimally) from the Pamir Mountains to the Altai Mountains. Between the Tian Shan and Altai mountains, in particular, there are no deserts above the 1,000-m altitude (thus, they would not lie within the "mountain" corridor). Geographically, the Dzhungar Mountains extend the broad north-south chain of Asian mountains that is separated only by the Ili River basin and the grasslands of the Dzhungarian gate. Tigers or not, the eastern steppe "zone" is, in effect, a mountainous one that extends well to the south because of the consistent impact of vertical environmental conditions on highland grassland ecology (Frachetti 2008). I did not include Mongolia in my discussion, but I agree with Kradin that it is also an important consideration. So many rabbits, so little time.

Anthony also appears dubious of the social ties along the IAMC because he sees too few sites to evince the connections, especially considering the Altai. He would prefer better "cultural" justifications-ceramic decorations, burial poses, and the like-to illustrate a source and endpoint of my proposed corridor. But this is precisely what I aimed to avoid. In fact, 
I expect that the forthcoming analyses of these societies' ceramic production will reveal considerable regional diversity even if there are shared motifs (forthcoming dissertation research by Paula Doumani). My approach instead focused on the ecological similarity evident in pastoralist strategies, which shaped a diffuse alignment of institutions among diverse mountain communities. Beyond Sarazm and Begash, sites such as Jukov and others (kindly reiterated by Lamberg-Karlovsky) illustrate linkages among mountain pastoralists at least by the early third millennium BC. There are admittedly fewer known sites in the late Eneolithic and Early Bronze Age, but by the middle Bronze Age many more are evident. I may add, however, that while not yet ready for publication, the results of my 2011 pilot survey and excavations in the Malguzar Mountains of eastern Uzbekistan illustrate without question that the mountains of inner Asia were highly populated by pastoralists in prehistory. Forthcoming dates will tell how ancient this occupation is, but even the currently available data shape an important geographic arena for early pastoralism along the IAMC.

Lamberg-Karlovsky's comment further reiterates that the IAMC is not a fantastical proposal but rather a historically documented landscape where numerous interregional passages and trade networks were forged across the mountains. He notes the tracks of travelers and the work of earlier scholars who identified material and institutional ties between societies living along the proposed corridor. Lamberg-Karlovsky's comments also highlight my point that a rapidly growing community of international researchers working on the ground across central Asia is quickly filling the perceived lacuna of evidence for the IAMC. The IAMC is significant because it widens our perspective on how interactions at local scales engender macroscale changes. The proposed mechanics of interactions along the IAMC were not wide ranging, but they shaped diverse extensions of connective tissue that ultimately linked societies of western China with those of central Asia, the steppe, and beyond. This was the formative participatory arena for a unique, "nonuniformly" arranged political economy that was paradoxically differentiated and interconnected.

In his perceptive commentary, Kradin laments that the political organization of steppe pastoralists is still relatively misunderstood and thus remains a major theme for current and future investigation. I might amend his statement to say that part of the issue may be that the organizational aspects of steppe societies that we can trace archaeologically are often not viewed as relevant to canonically defined political systems; thus, we remain mired in cultural typologies. In essence, I hope that the idea of nonuniform institutional complexity exposes the complex working parts of a wholly different political order. I have proposed a political system for the Eurasian steppe that defies the socioevolutionary trappings of organized political economy as we know it, locating institutional alignments outside the grasp of large-scale hegemonies and instead activating the political impact of mobile and itinerant constellations of power and ideology.

To this point, I found a comment by Rogers to be incredibly important: "These cultural trajectories provide a muchneeded wake-up call for how we understand the entire emergence and development of 'civilization,' or more appropriately, early states and empires. Current theory is almost exclusively envisioned on the basis of sedentary agricultural societies." Although there is much to glean from models of heterarchy and other "alternatives" to chiefdoms and states, I am increasingly convinced that the mobile societies of inner Asia—and comparable societies around the world—built incredibly complex political systems without a clear sense of the organizational structures (i.e., the institutions) of all the active participants.

Undoubtedly, I still have a long way to go to demonstrate the functionality of this idea. My forthcoming work will address this in finer, regional detail. Yet I hope I am not alone in seeking out different institutional morphologies. I was encouraged that Kradin ventured to think about how nonuniform institutions might relate to "heterarchical" aspects of the Khitan Federation, for example. Although Potts would have liked more detail in some of my examples, he remarked that his own examples sprang to mind in considering my argument. Getting people to think differently about how innovations, materials, and ideas transfer was exactly my goal. The concept of nonuniform institutional alignment opens a door to consideration of societies left out of the discussion about regional political hegemony and contextualizes the scales of their practical engagements through archaeologically realistic eyes. If nonuniform institutional alignment can be illustrated more comprehensively and applied more widely, it may allow us to see the development of civilization under completely different terms.

Hanks and Doonan are concerned that my model is too global and thus brushes over the gritty practical levels where institutions are derived. I agree that theory and material evidence are always clearer when outlined in small chunks, and I am guilty here of biting off a large one. Although they wanted more regional context for each of my examples, they still managed to identify a very important condition of nonuniform complexity that I did not explicitly discuss in detail. They remark that "if political establishments align themselves through shared yet restricted elements of material culture, then perhaps it is the localized strategies by which individual communities secured their right to participate in this arena that demand our attention." This is spot on. The key concept they identify is "participation," and I am currently completing an article about this deep and multivalent concept, particularly as it applies to "nonuniform" institutional formation. Participation is key to institutional formation in Eurasian prehistory because it defines the social circuitry, growth, and geographic expansion of practical engagements between communities.

So, to use the example raised by Hanks and Doonan about 
the anachronistic adoption of chariots from their source to their ultimate final distribution across Eurasia, I suggest that it is not essential within a nonuniform institutional model that the Chinese ever knew about the employment of these two-wheeled "power wagons" at Sintashta. In fact, nonuniform alignments implicitly allow for long-distance connections to be discontinuous and indirect (spatially and chronologically). Various tracks of institutional "participation" are determined by the active connections that exist between regional players at any given time. It is important, therefore, to identify the shifting nodes and trajectories among participating parties and define the mechanisms by which they "buy into" institutional ideas-in this case that chariots were symbols (and sometimes actual mechanisms) of power. We can then trace the geographic and social circuitry of this institution throughout time. By virtue of its general definition as a mode of integration, "participation" represents an essential engine that propels institutional alignments and fragmentations within social organizations and allows their boundaries to expand beyond conventionally conceived hegemonic constraints (e.g., states). "Participation" remains generally undertheorized but can be archaeologically traced in a variety of specific cases. Please be on the lookout for my forthcoming article and detailed treatment of this very important anthropological concept.

I thank all the commentators for their challenging thoughts; it is a testimony to the active community of researchers that we have such compelling themes to ponder for some time. I look forward to further exploring these ideas in my forthcoming work and certainly look forward to the continuing contributions of my distinguished colleagues.

-Michael D. Frachetti

\section{References Cited}

Akhinzhanov, S. M., L. A. Makarova, and T. N. Nurumov. 1992. K istorii skotovodstva $i$ okhoty $v$ Kazakhstane. Almaty, Kazakhstan: Gylym.

Akishev, K. A., and G. A. Kushaev. 1963. Drevnyaya kul'tura sakov i usunei dolini reka Ili. Alma-Ata, Kazakhstan: Nauka.

Aldenderfer, Mark. 2006. Modeling plateau peoples: the early human use of the world's high plateaux. World Archaeology 38(3):357370.

Alekhin, Yu. P., and A. V. Gal'chenko. 1995. K voprosu o drevneishem skotovodstve Altaya: po materialam poseleniya Kolybanskoe I. In Kul'tury drevnikh narodov stepnoi Evrazii i fenomen protogorodsckoi tsivilizatsii yuzhnogo Urala, pt. 5, bk. 1 of Rossiya i vostok: problemu vzaimodeistviya. Pp. 22-26. Chelyabinsk, Russia: 3-i Mezhdunarodnoi Nauchnoi Konferentsii.

Alimov, Kamildžan, Nikolaus Boroffka, Mira Bubnova, Jurij Burjakov, Jan Cierny, Jussuf Jakubov, Joachim Lutz, et al. 1998. Prähistorischer Zinnbergbau in Mittelasien: Vorbericht der Kampagne 1997. Eurasia Antiqua 4:137-199. [DTP]

Alizadeh, Abbas. 2010. The rise of the highland Elamite state in southwestern Iran. Current Anthropology 51(3):353-383.

Anthony, David W. 1998. The opening of the Eurasian steppe at 2000 BCE. In The Bronze Age and early Iron Age peoples of eastern central
Asia. Victor H. Mair, ed. Pp. 94-113. Philadelphia: University of Pennsylvania Museum.

- 2007. The horse, the wheel, and language: how Bronze-Age riders from the Eurasian steppes shaped the modern world. Princeton, NJ: Princeton University Press.

2009. The Sintashta genesis: the roles of climate change, warfare, and long-distance trade. In Social complexity in prehistoric Eurasia: monuments, metals, and mobility. Bryan K. Hanks and Katheryn M. Linduff, eds. Pp. 47-73. Cambridge: Cambridge University Press.

Anthony, David W., Dorcas R. Brown, Emmett Brown, Audrey Goodman, Aleksandr A. Khokhlov, Pavel A. Kosintsev, Pavel F. Kuznetsov, et al. 2005. The Samara Valley project: late Bronze Age economy and ritual in the Russian steppes. Eurasia Antiqua 11: 395-417.

Antipina, Elena E. 1997. Metody rekonstruktsii osobennostei skotovodstva na yuge vostochnoi Evropy v epokhy bronzy. Rossiskaya Arkheologiya 3:20-32.

Arnold, Bettina, and Blair Gibson, eds. 1995. Celtic chiefdom, Celtic state. Cambridge: Cambridge University Press. [NNK]

Avanessova, N. A. 1996. Pasteurs et agriculteurs de la Vallee du Zeravshan (Ouzbekistan) au debut de l'age du Bronze: relations et influences mutuelles. In Sarazm (Tadjikistan) céramiques: chalcolithique et bronze ancien. Bertille Lyonnet, ed. Pp. 117-130. Mémoire de la Mission Archéologique Française en Asie Centrale 7. Paris: De Boccard.

Avanessova, N. A., and D. M. Dzhurakulova. 2008. Drevneishie nomady Zeravshana. In Kul'tura nomadov Tsentral'noi Azii: materialy mezhdunarodnoi konferentsii, Samarkand, November 22-24, Noyabrya 2007. Sh. R. Pidaev, ed. Pp. 13-33. Samarkand, Uzbekistan: MITSAI.

Barfield, Thomas J. 2001. The shadow empires: imperial state formation along the Chinese-nomad frontier. In Empires: perspectives from archaeology and history. Susan E. Alcock, Terence N. D'Altroy, Kathleen D. Morrison, and Carla M. Sinopoli, eds. Pp. 10-41. Cambridge: Cambridge University Press. [NNK]

Barker, Graeme. 2006. The agricultural revolution in prehistory: why did foragers become farmers? Oxford: Oxford University Press.

Barth, Fredrik. 1961. Nomads of South Persia: the Basseri tribe of the Khamseh confederacy. Boston: Little, Brown.

Barynkin, P. P. 1998. Stoyanka Kyzl-khak P-pamyatnik rannei bronzi Severnogo Prikaspiya. In Problemy drevnei istorii Severnogo Prikaspiya. I. B. Vasil'ev, ed. Pp. 179-193. Samara, Russia: Ministerstvo obshego i professionapvnogo obrazovaniya Rossiyskoy Federatsii.

Barynkin, P. P., and E. V. Kozin. 1998. Prirodno-klimaticheskie i kul'turno-demograficheskie protsessi v severnom prikaspii v rannem i srednem golotsene. In Problemy drevnei istorii Severnogo Prikaspiya. I. B. Vasil'ev, ed. Pp 66-83. Samara, Russia: Ministerstvo obshego i professionapvnogo obrazovaniya Rossiyskoy Federatsii.

Barynkin, P. P., and I. B. Vasil'ev. 1988. Stoyanka khvalinskoi zneoliticheskoi kul'turi kara-khuduk v severnom prikaspii. In Arkheologicheskie kul'tury Severnogo Prikaspiya: mezhvuzovskii sbornik nauchnykh trudov. Nikolai Y. Merpert, ed. Pp. 123-142. Kuybyshev, Russia: Kuyoyshevskii gosudarstvennyi pedagogicheskiy institute imeni V. V. Kuitshev.

Beck, Lois. 1991. Nomad: a year in the life of a Qashqa'i tribesman in Iran. Berkeley: University of California Press.

Bendrey, Robin. 2011. Some like it hot: environmental determinism and the pastoral economies of the later prehistoric Eurasian steppe. Pastoralism: Research, Policy and Practice 1:8.

Benecke, Norbert. 1997. Archaeozoological studies on the transition from the Mesolithic to the Neolithic in the north Pontic region. Anthropozoologica 25:631-641.

Benecke, Norbert, and Angela von den Driesch. 2003. Horse ex- 
ploitation in the Kazakh steppes during the Eneolithic and Bronze Age. In Prehistoric steppe adaptation and the horse. Marsha Levine, Colin Renfrew, and Katie Boyle, eds. Pp. 69-82. McDonald Institute Monographs. Cambridge: McDonald Institute for Archaeological Research.

Bernbeck, Reinhard. 2008. An archaeology of multisited communities. In The archaeology of mobility: nomads in the Old and in the New World. Hans Barnard and Willeke Wendrich, eds. Pp. 43-77. Los Angeles: Cotsen Institute of Archaeology, University of California, Los Angeles.

Besenval, Roland, and Abdullah Isakov. 1989. Sarazm et les débuts du peuplement agricole dans la région de Samarkand. Arts Asiatiques 44:5-20. [DTP]

Blanton, Richard, and Lane Fargher. 2008. Collective action in the formation of pre-modern states. New York: Springer. [NNK]

Bobomulloev, S. 1998. Verkhov'ya Zarafshana. Dushanbe, Tajikistan: Instituta istorii, arkheologii, i etnografii Respubliki Tadjikistan.

- 1999. Discovery of a Bronze Age tomb on the Upper Zeravshan. Stratum Plus 2:307-314. [In Russian.] [CCL-K]

Bobrov, Vladimir V. 1988. On the problem of interethnic relations in south Siberia in the third and second millennia BC. Arctic Anthropology 25(2):30-46. [DWA]

Bold, Bat-Ochir. 2001. Mongolian nomadic society: a reconstruction of the "medieval" history of Mongolia. Richmond, UK: Curzon. [NNK]

Bondarenko, Dmitri M. 2007. Homoarchy as a principle of sociopolitical organization. Anthropos 102(1):187-199. [NNK]

Boroffka, Nikolaus. 1998. Bronze- und früheisenzeitliche Geweihtrensenknebel aus Rumänien und ihre Beziehungen. 2. Alte Funde aus dem Museum für Geschichte Aiud. Eurasia Antiqua 4:81-135. [DTP]

Boyle, Katie, Colin Renfrew, and Marsha Levine, eds. 2002. Ancient interactions: east and west in Eurasia. McDonald Institute Monographs. Cambridge: McDonald Institute for Archaeological Research.

Burmeister, Stefan. 2010. Transport im 3. Jahrtausend vor Christus: waren die Wagen ein geeignetes Transportmittel im Überlandverkehr? In Von Majkop bis Trialeti: Gewinnung und Verbreitung von Metallen und Obsidian in Kaukasien im 4.-2. Jt. v. Chr. Svend Hansen, Andreas Hauptmann, Ingo Motzenbäcker, and Ernst Pernicka, eds. Pp. 224-235. Kolloquien zur Vor- und Frühgeschichte Band 13. Bonn: Habelt. [DTP]

Chang, Claudia, Norbert Benecke, Fedor P. Grigoriev, Arlene M. Rosen, and Perry A. Tourtellotte. 2003. Iron Age society and chronology in southeast Kazakhstan. Antiauity 77(296):298-312.

Chen, Kwang-Tzuu, and Fredrik T. Hiebert. 1995. The late prehistory of Xinjiang in relation to its neighbors. Lournal of World Prehistory 9(2):243-300.

Cheng, T. K. 1960. Shang China, vol. 2 of Archaeology in China. Cambridge: Heffer.

Chernykh, Evgenii N. 1992. Ancient metallurgy in the USSR: the early metal age. Cambridge: Cambridge University Press.

. 2004. Kargaly: the largest and most ancient metallurgical complex on the border of Europe and Asia. In Metallurgy in ancient eastern Eurasia from the Urals to the Yellow River. Katheryn M. Linduff, ed. Pp. 223-238. Lewiston, NY: Mellen.

- 2009. Formation of the Eurasian steppe belt cultures: viewed through the lens of archaeometallurgy and radiocarbon dating. In Social complexity in prehistoric Eurasia: monuments, metals, and mobility. Bryan K. Hanks and Katheryn M. Linduff, eds. Pp. 115145. Cambridge: Cambridge University Press.

Chernykh, E. N., L. I. Avilova, L. B. Orlovskaya, and S. V. Kuz'minykh. 2002. Metallurgiya v tsirkumpontiiskom areale: ot edinstva k raspadu. Rossiiskaya Arkheologiya 1(1):5-23.

Chernykh, E. N., S. V. Kuz'minykh, and L. B. Orlovskaya. 2004. Ancient metallurgy of northern Eurasia: from the Urals to the Sayano-Altai. In Metallurgy in ancient eastern Eurasia from the
Urals to the Yellow River. Katheryn M. Linduff, ed. Pp. 15-36. Lewiston, NY: Edwin Mellen.

Chernysh, E. K. 1982. Eneolit Pravoberezhnoi Ukrainy i Moldavii. In Eneolit SSSR: Arkheologiya SSSR. V. M. Masson and N. Y. Merpert, eds. Pp. 165-240. Moscow: Nauka.

Chessa, Bernardo, Filipe Pereira, Frederick Arnaud, Antonio Amorim, Félix Goyache, Ingrid Mainland, Rowland R. Kao, et al. 2009. Revealing the history of sheep domestication using retrovirus integrations. Science 324(5926):532-536.

Danilenko, V. N. 1974. Éneolit Ukrainy: ètnoistoricheskoe issledovanie. Kiev: Naukova dumka.

Degtyaryova, A. D. 2010. Istoriya metalloproizvodstva yuzhnogo Zaural'ya v epohu bronzy. Novosibirsk, Russia: Nauka. [AVE]

Dergachev, V. A. 2007. O skipetrakh, o loshadyakh, o voine. St. Petersburg: Nestor-Istoriya. [DWA]

Di Cosmo, Nicola. 1994. Ancient inner Asian nomads: their economic basis and its significance in Chinese history. Journal of Asian Studies 53(4):1092-1126.

2003. Ancient China and its enemies: the rise of nomadic power in east Asian history. Cambridge: Cambridge University Press.

Dolukhanov, Pavel. 2002. Alternative revolutions: hunter-gatherers, farmers and stock-breeders in the northwestern Pontic area. In Ancient interactions: east and west in Eurasia. Katie Boyle, Colin Renfrew, and Marsha Levine, eds. Pp. 13-24. Cambridge: McDonald Institute for Archaeological Research.

Epimakhov, Andrei V. 2007. Otnositel'naya i absolutnaya khronologia sintashtinskih pamyatnikov $\mathrm{v}$ svete radiokarbonnyh datirovok. Problemy istorii, filologii, kul'tury 17:402-421. [AVE]

_ 2009a. Bronzovyi vek yuzhnogo Urala: ekonomicheskaya stabil'nost' i social'naya dinamika. Problemy istorii, filologii, kul'tury 1(23):180-202. [AVE]

- 2009b. Settlements and cemeteries of the Bronze Age of the Urals: the potential for reconstructing early social dynamics. In Social complexity in prehistoric Eurasia: monuments, metals, and mobility. Bryan K. Hanks and Katheryn M. Linduff, eds. Pp. 7490. Cambridge: Cambridge University Press.

. 2010. Bronzovyi vek Yuzhnogo Urala: ekonomicheskaya i social'naya evol'utziya. Ural'skii istoricheskii vestnik 2:31-37. [AVE] Falkenhausen, Lothar von. 2006. Ideas, debates, and perspectives, vol. 2 of Chinese society in the age of Confucius (1000-250 BC): the archaeological evidence. Los Angeles: Cotsen Institute of Archaeology, University of California, Los Angeles.

Flad, Rowan, Shuicheng Li, Xiaohong Wu, and Zhijun Zhao. 2010. Early wheat in China: results from new studies at Donghuishan in the Hexi Corridor. Holocene 20(6):955-965.

Frachetti, Michael D. 2008. Pastoralist landscapes and social interaction in Bronze Age Eurasia. Berkeley: University of California Press.

. 2009. Differentiated landscapes and non-uniform complexity among Bronze Age societies of the Eurasian steppe. In Social complexity in prehistoric Eurasia: monuments, metals, and mobility. Bryan K. Hanks and Katheryn M. Linduff, eds. Pp. 19-46. Cambridge: Cambridge University Press.

Frachetti, Michael D., and Norbert Benecke. 2009. From sheep to (some) horses: 4500 years of herd structure at the pastoralist settlement of Begash (southeastern Kazakhstan). Antiquity 83(322): 1023-1037.

Frachetti, Michael D., and Alexei N. Mar'yashev. 2007. Long-term occupation and seasonal settlement of eastern Eurasian pastoralists at Begash, Kazakhstan. Journal of Field Archaeology 32(3):221-242.

Frachetti, Michael D., Robert S. Spengler, Gayle J. Fritz, and Alexei N. Mar'yashev. 2010. Earliest evidence of broomcorn millet and wheat in the central Eurasian steppe region. Antiauity 84(326): 993-1010.

Freidel, David A. 1983. Political systems in lowland Yucatan: dynamics and structure in Maya settlement. In Prehistoric settlement pat- 
terns: essays in honor of Gordon R. Willey. Evon Z. Vogt and Richard M. Leventhal, eds. Pp. 375-386. Albuquerque: University of New Mexico Press.

Fuller, Dorian Q. 2001. Harappan seeds and agriculture: some considerations. Antiquity 75(288):410-414.

Gellner, Ernst. 1988. State and society in Soviet thought. Oxford: Blackwell. [NNK]

Gening, V. F., G. V. Zdanovich, and V. V. Gening. 1992. Sintashta. Chelyabinsk, Russia: Yuzhnoe-Uralskoe Knizhkoe Izdatel'stvo.

Gimbutas, Marija. 1965. Bronze Age cultures in central and eastern Europe. The Hague: Mouton.

Golden, Peter B. 2001. Ethnicity and state formation in pre-Činggisid Turkic Eurasia. Bloomington: Indiana University, Department of Central Eurasian Studies. [NNK]

2003. Nomads and their neighbours in the Russian steppe: Turks, Khazars and Qipchaqs. Burlington, VT: Ashgate Variorum. [NNK]

Goloskokov, V. P. 1984. Flora Dzhungarskogo Alatau. Almaty, Kazakhstan: Nauka Kazakhskogo SSR.

Good, Irene. Forthcoming. When East met West: interpretive problems in assessing Eurasian contact and exchange in antiquity. In Proceedings, 5th International Congress on the Archaeology of the Ancient Near East, Madrid. Allison Betts and Fiona Kidd, eds. Louvain, Belgium: Peeters.

Görsdörf, Jochen, Hermann Parzinger, and Anatoli Nagler. 2001. New radiocarbon dates of the north Asian steppe zone and its consequences for the chronology. Radiocarbon 43(2B):1115-1120.

- $2004 .{ }^{14} \mathrm{C}$ dating of the Siberian steppe zone from Bronze Age to Scythian time. In Impact of the environment on human migration in Eurasia. E. Marian Scott, Andrey Yu. Alekseev, and Ganna Zaitseva, eds. Pp. 83-90. New York: Kluwer.

Granovetter, Mark S. 1973. The strength of weak ties. American Journal of Sociology 78(6):1360-1380.

Grinin, Leonid E., Robert L. Carneiro, Dmitri M. Bondarenko, Nikolay N. Kradin, and Andrey V. Korotayev, eds. 2004. The early state, its alternatives and analogues. Volgograd, Russia: Uchitel. [NNK]

Gubaev, Abdyrakhman, Gennadij Koshelenko, and Maurizio Tosi. 1998. Archaeological map of the Murghab Delta: preliminary reports 1990-1995. Rome: Istituto Italiano per l'Africa et l'Oriente. [CCL-K]

Haas, Jonathan, ed. 2001. From leaders to rulers. New York: Kluwer Academic/Plenum. [NNK]

Hanks, Bryan. 2010. Archaeology of the Eurasian steppes and Mongolia. Annual Review of Anthropology 39:469-486.

Hanks, Bryan K., A. V. Epimakhov, and A. C. Renfrew. 2007. Towards a refined chronology for the Bronze Age of the southern Urals, Russia. Antiquity 81(312):353-361.

Hanks, Bryan K., and Katheryn M. Linduff, eds. 2009. Social complexity in prehistoric Eurasia: monuments, metals, and mobility. Cambridge: Cambridge University Press.

Harlan, Jack R. 1971. Agricultural origins: centers and non-centers. Science 174(4008):468-474.

Harris, David R. 1996. The origins and spread of agriculture and pastoralism in Eurasia. Washington, DC: Smithsonian Institution Press.

Harrower, Michael J., Joy McCorriston, and A. Catherine D'Andrea. 2010. General/specific, local/global: comparing the beginnings of agriculture in the Horn of Africa (Ethiopia/Eritrea) and southwest Arabia (Yemen). American Antiauity 75(3):452-472.

Hemphill, Brian E., and J. P. Mallory. 2004. Horse-mounted invaders from the Russo-Kazakh steppe or agricultural colonists from western central Asia? a craniometric investigation of the Bronze Age settlement of Xinjiang. American Journal of Physical Anthropology 124(3):199-222.

Hiebert, Fredrik T. 1998. Central Asians on the Iranian Plateau: a model for Indo-Iranian expansionism? In The Bronze and early Iron Age peoples of eastern central Asia, vol. 1. Victor H. Mair, ed. Pp. 148-161. Philadelphia: University of Pennsylvania Museum.

Hiendleder, Stefan, Bernhard Kaupe, Rudolf Wassmuth, and Axel Janke. 2002. Molecular analysis of wild and domestic sheep questions current nomenclature and provides evidence for domestication from two different subspecies. Proceedings of the Roval Society B: Biological Sciences 269(1494):893-904.

Hiendleder, Stefan, K. Mainz, Yves Plante, and Heidrun Lewalski. 1998. Analysis of mitochondrial DNA indicates that domestic sheep are derived from two different ancestral maternal sources: no evidence for contributions from Urial and argali sheep. Journal of Heredity 89(2):113-120.

Hole, Frank. 1987. The archaeology of western Iran: settlement and society from prehistory to the Islamic conquest. Washington, DC: Smithsonian Institution Press.

Honeychurch, William, and Chunag Amartuvshin. 2006. States on horseback: the rise of inner Asian confederations and empires. In Archaeology of Asia. Miriam T. Stark, ed. Pp. 255-278. London: Blackwell. [NNK]

- 2007. Hinterlands, urban centers, and mobile settings: the "new" Old World archaeology from the Eurasian steppe. Asian Perspectives 46(1):36-64.

Ingold, Tim. 2000. The perception of the environment: essavs on livelihood, dwelling and skill. London: Routledge.

Isakov, A. I. 1991. Sarazm k voprosu stanovlenija rannezemledel'čskoj kultury zeravšanskoj doliny raskopki 1977-1983. Dushanbe, Tajikistan: Donish.

Isakov, A. I., Philip L. Kohl, C. C. Lamberg-Karlovsky, and R. Maddin. 1987. Metallurgical analysis from Sarazm, Tadjikistan SSR. Archaeometry 29(1):90-102. [DWA]

Kalieva, S. S., and V. N. Logvin. 1997. Skotovody Turgaya $v$ tret'em tysyacheletii do nashei ery. Kustanai, Kazakhstan: Akademiia Nauk.

Kelekna, Pita. 2009. The horse in human history. Cambridge: Cambridge University Press.

Kenoyer, Jonathan Mark. 2004. Chronology and interrelations between Harappa and central Asia. Journal of the Japanese Society for West Asian Archaeology 5:38-45.

. 2008. Indus and Mesopotamian trade networks: new insights from shell and carnelian artifacts. In Intercultural relations between south and southwest Asia: studies in commemoration of E. C. L. During-Caspers (1934-1996). Eric Olijdam and Richard H. Spoor, eds. Pp. 19-28. British Archaeological Research International Series S1826. Oxford: Archaeopress.

. 2009. Carts and wheeled vehicles of the Indus civilization: new evidence from Harappa, Pakistan. In Linguistics, archaeology, and the human past: occasional paper 9. Toshiki Osada and Akenori Uesugi, eds. Pp. 1-34. Kyoto: Research Institute for Humanity and Nature.

Keyser, Christine, Caroline Bouakaze, Eric Crubézy, Valerie G. Nikolaev, Daniel Montagnon, Tatiana Reis, and Bertrand Ludes. 2009. Ancient DNA provides new insights into the history of south Siberian Kurgan people. Human Genetics 126(3):395-410.

Khazanov, Anatoly M. 1978. Characteristics of communities in the Eurasian steppes. In The nomadic alternative: modes and models of interaction in the African-Asian deserts and steppes. Wolfgang Weissleder, ed. Pp. 119-126. Paris: Mouton.

- 1984. Nomads and the outside world. Cambridge: Cambridge University Press. [NNK]

- 1994. Nomads and the outside world. 2nd edition. Madison: University of Wisconsin Press.

Kiryushkin, Yu. F., S. P. Grushin, and D. V. Panin. 2009. Radiouglerodnaya khronologiya pamyatnikov epokhi rannego metalla Altaya. In Rol' estestvenno-nauchnykh metodov $v$ arkheologicheskikhb issledovaniyakh. Pp. 120-124. Barnaul, Russia: Izdatel'stvo Altayskogo Gosudarstennogo Universiteta. 
Kislenko, Aleksandr, and Nataliya Tatarintseva. 1999. The eastern Ural steppe at the end of the Stone Age. In Late prehistoric exploitation of the Eurasian steppe. By Marsha Levine, Yuri Rassamakin, Aleksandr Keslenko, and Nataliya Tatarintseva. Pp. 183216. Cambridge: McDonald Institute for Archaeological Research.

Kohl, Philip L. 1987. The use and abuse of world systems theory: the case of the pristine west Asian state. Advances in Archaeological Method and Theory 11:1-35.

. 2007. The making of Bronze Age Eurasia. Cambridge: Cambridge University Press.

. 2008. Shared social fields: evolutionary convergence in prehistory and contemporary practice. American Anthropologist 110(4):495-506.

. 2009a. The Maikop singularity: the unequal accumulation of wealth on the Bronze Age Eurasian steppe? In Social complexity in prehistoric Eurasia: monuments, metals, and mobility. Bryan K. Hanks and Katheryn M. Linduff, eds. Pp. 91-104. Cambridge: Cambridge University Press.

- 2009b. Perils of carts before horses: linguistic models and the underdetermined archaeological record. American Anthropologist 111(1):109-111.

Korobkova, G. F., and O. G. Shaposhnikova. 2005. Poselenie Mikhailovka: etalonnyi pamyatnik drevneyamnoi kul'tury. St. Petersburg: Evropeiskii dom.

Korvin-Piotrovskii, O. G., and T. G. Movsha. 1999. Kolisnii transport tryilsko-kukutenskoi spilnosti. In Kul'turologichni Studii 2. Pp. 7078. Kiev, Ukraine: KM Academia.

Koryakova, Ludmila N. 2002. Social landscape of central Eurasia in the Bronze and Iron ages: tendencies, factors and limits of transformation. In Regional specifics in light of global models BC: complex societies of central Eurasia from the 3rd to the 1st millennium. Vol. 1. Karlene Jones-Bley and D. Zdanovich, eds. Pp. 97-118. Journal of Indo-European Studies Monograph Series 45. Washington, DC: Institute for Study of Man. [NNK]

Koryakova, Ludmila N., and Andrey V. Epimakhov. 2007. The Urals and western Siberia in the Bronze and Iron ages. Cambridge: Cambridge University Press.

Kosarev, M. F. 1984. Zapadnaia Sibir' v drevnosti. Moscow: Nauka.

Kosintzev, Pavel A. 2006. The human-horse relationship on the European-Asian border in the Neolithic and Early Iron Age. In Horses and humans: the evolution of human/equine relationships. Sandra L. Olsen, Susan Grant, Alice M. Choyke, and László Bartosiewicz, eds. Pp. 127-135. British Archaeological Research International Series 1560. Oxford: BAR International. [AVE]

Kotova, Nadezhda S. 2003. Neolithization in Ukraine. British Archaeological Research International Series 1109. Oxford: BAR International. [SLO]

- 2008. Early Eneolithic in the Pontic steppes. British Archaeological Research International Series 1735. Oxford: Archaeopress.

Kradin, Nikolay N. 2002. Nomadism, evolution, and world-systems: pastoral societies in theories of historical development. Lournal of World-System Research 8(3):368-388. [NNK]

. 2008. Early state theory and the evolution of pastoral nomads. Social Evolution and History 7(1):107-130.

Kradin, Nikolay N., Dmitri Bondarenko, and Thomas Barfield, eds. 2003. Nomadic pathways in social evolution. Moscow: Center for Civilizational and Regional Studies of the Russian Academy of Sciences. [NNK]

Kradin, Nikolay N., and Tatyana D. Skrynnikova. 2006. Imperiya Chingis-Khana [The Genghis Khan empire]. Moscow: Vostochnaya literatura RAN. [NNK]

- 2009. "Stateless head": notes on revisionism in the studies of nomadic societies. Ab Imperio 4(4):117-128. [NNK]

Krause, Rüdiger, Ludmila N. Korjakova, J. Fornasier, S. V. Šarapova, A. V. Epimachov, S. E. Panteleeva, N. A. Bersenev, et al. 2010. Befestigte Siedlungen der bronzezeitlichen Sintašta-Kultur im
Trans-Ural, Westsibirien (Russische Föderation). Eurasia Antiqua 16:97-129. [AVE]

Kremenetski, Constantine V. 2003. Steppe and forest-steppe belt of Eurasia: Holocene environmental history. In Prehistoric steppe adaptation and the horse. Marsha Levine, Colin Renfrew, and Katie Boyle, eds. Pp. 11-28. Cambridge: McDonald Institute for Archaeological Research.

Kuz'mina, Elena E. 1986. Drevneishie skotovody ot Urala do Tian'Shania. Frunze: Ilim.

. 1994. Otkuda prishli indoarii? material'naia kul'tura plemen andronovskoi obshchnosti i proiskhozhdenie indoirantsev. Moscow: MGP Kalina.

- 2007. The origin of the Indo-Iranians. Leiden: Brill. . 2008. The prehistory of the Silk Road. Philadelphia: University of Pennsylvania Press.

Kuz'mina, I. B. 1988. Melkopitayushie severnogo prikaspiya v golopene. In Arkheologicheskie kul'tury Severnogo Prikaspiya: mezhduzovskii sbornik nauchnykh trudov. N. Y. Merpert, ed. Pp. 173189. Kuybyshev, Russia: Kuybyshevskii gosudarstvennyi pedagogicheskiy institute imeni V. V. Kuitshev.

Lamberg-Karlovsky, C. C. 1974. Urban interaction on the Iranian Plateau: excavations at Tepe Yahya 1967-1973. London: Oxford University Press.

- 2002. Archaeology and language: the Indo-Iranians. Current Anthropology 43(1):63-88.

. 2003. Civilization, state or tribe? Bactria and Margiana in the Bronze Age. Review of Archaeology 24(1):11-21.

. 2009. Structure, agency, and commerce in the ancient Near East. Iranica Antiqua 44:47-88.

Lamberg-Karlovsky, C. C., and Maurizio Tosi. 1973. Shahr-ī Sokhta and Tepe Yahya: tracks on the earliest history of the Iranian Plateau. Rome: IsMEO.

Lansdell, Henry. 1885. Russian central Asia. Boston: Houghton Mifflin. [CCL-K]

Lattimore, Owen. 1940. Inner Asian frontiers of China. American Geographical Society Research Series, no. 21. New York: American Geographical Society.

Law, Randall. 2006. Moving mountains: the trade and transport of rocks and minerals within the Indus Valley region. In Space and spatial analysis in archaeology. Elizabeth C. Robertson, Jeffrey D. Seibert, Deepika C. Fernandez, and Marc U. Zender, eds. Pp. 301313. Albuquerque: University of New Mexico Press.

Levine, Marsha. 2005. Domestication and early history of the horse. In The domestic horse: the origins, development and management of its behaviour. Daniel Mills and Sue McDonnell, eds. Pp. 5-22. Cambridge: Cambridge University Press.

Levine, Marsha, Colin Renfrew, and Katie Boyle, eds. 2003. Prehistoric steppe adaptation and the horse. Cambridge: McDonald Institute for Archaeological Research.

Li, Chunxiang, Hongjie Li, Yinqiu Cui, Chengzhi Xie, Dawei Cai, Wenying Li, Victor H. Mair, et al. 2010. Evidence that a west-east admixed population lived in the Tarim Basin as early as the early Bronze Age. BMC Biology 8:15.

Linduff, Katheryn M. 2003. A walk on the wild side: late Shang appropriation of horses in China. In Prehistoric steppe adaptation and the horse. Marsha Levine, Colin Renfrew, and Katie Boyle, eds. Pp. 139-162. Cambridge: McDonald Institute for Archaeological Research.

. 2004. Silk Road exchange in China. Sino-Platonic Papers 142. Philadelphia: Department of East Asian Languages and Civilizations, University of Pennsylvania.

. 2009. Introduction. In Social complexity in prehistoric Eurasia: monuments, metals, and mobility. Bryan K. Hanks and Katheryn M. Linduff, eds. Pp. 107-114. Cambridge: Cambridge University Press.

Litvinskij, Boris A., Aleksei P. Okladnikov, and Vladimir A. Ranov. 
1962. Drevnosti Kaŭrak-kumov: drevneishchaiya istoriiya Severnogo Tadjikistana. Dushanbe, Tajikistan: Izdatel'stvo Akademii Nauk Tadzikskoj SSR.

Lyonnet, Bertille, ed. 1996. Sarazm (Tajikistan): céramiques (chalcolithiques et bronze ancien). Mémoire de la Mission Archéologique Française en Asie Centrale 7. Paris: de Boccard.

Mallory, James P. 1989. In search of the Indo-Europeans. London: Thames \& Hudson.

Marshall, Fiona, and Elisabeth Hildebrand. 2002. Cattle before crops: the beginnings of food production in Africa. Iournal of World Prehistory 16(2):99-143.

Mar'yashev, A. N., and A. A. Goryachev. 1998. Naskal'nye izobrazheniya semirech'ya. Almaty, Kazakhstan: Akademiia Nauk.

Masanov, N. E. 1995. Kochevaia tsivilizatsiia kazakhov osnovy zhiznedeiatel nosti nomadnogo obshchestva. Moscow: Sotsinvest, Gorizont.

Masson, V. M. 2006. Kul'turogenez drevneı̆ Tsentral'noŭ Azii. St. Petersburg: Filologicheskiu fakul'tet Sankt-Peterburgskogo gosudarstvennogo universiteta.

Masson, V. M., and V. I. Sarianidi. 1972. Central Asia: Turkmenia before the Achaemenids. London: Thames \& Hudson.

Meadow, Richard H. 1996. The origins and spread of agriculture and pastoralism in northwestern south Asia. In The origins and spread of agriculture and pastoralism in Eurasia. David R. Harris, ed. Pp. 309-412. London: University College London Press.

Mei, Jianjun. 2003. Qijia and Seima-Turbino: the question of early contacts between northwest China and the Eurasian steppe. Bulletin of the Museum of Far Eastern Antiquities 75:31-54.

- 2009. Early metallurgy and socio-cultural complexity: archaeological discoveries in northwest China. In Social complexity in prehistoric Eurasia: monuments, metals, and mobility. Bryan $\mathrm{K}$. Hanks and Katheryn M. Linduff, eds. Pp. 215-234. Cambridge: Cambridge University Press.

Mei, Jianjun, and Colin Shell. 1999. Existence of Andronovo cultural influence in Xinjiang during the second millennium. Antiquity 73(281):570-578. [CCL-K]

Merpert, Nikolai. 1974. Drevněshie skotovody Volzhsko-Ural'skogo mezhdurech'iya. Moscow: Nauka.

Miller-Rosen, Arlene, Claudia Chang, and Fedor P. Grigoriev. 2000. Paleoenvironment and economy of Iron Age Saka-Wusun agropastoralists in southeastern Kazakhstan. Antiquity 74(285):611623.

Moore, Katherine, Naomi F. Miller, Fredrik T. Hiebert, and Richard H. Meadow. 1994. Agriculture and herding in the early oasis settlements of the Oxus civilization. Antiquity 68(259):418-427.

Morales Muñiz, Arturo, and Ekaterina Antipina. 2003. Srubnaya fauna and beyond: a critical assessment of the archaeozoological information from the east European steppe. In Prehistoric steppe adaptation and the horse. Marsha Levine, Colin Renfrew, and Katie Boyle, eds. Pp. 329-352. Cambridge: McDonald Institute for Archaeological Research.

Murzaev, E. M. 1958. Srednyaya Aziya, fiziko-geograficheskaya kharakteristika. Moscow: Akademiia Nauk SSSR. [DWA]

Nikolova, Alla V., and Elke Kaiser. 2009. Die absolute Chronologie der Jamnaja-Kultur im nördlichen Schwarzmeergebiet auf der Grundlage erster dendrochronologischer Daten, mit einem Beitrag von K.-U. Heußner. Eurasia Antiqua 15:209-240. [DTP]

North, Douglas C. 1990. Institutions, institutional change, and economic performance. Cambridge: Cambridge University Press.

Oates, Joan. 2003. A note on the early evidence for horse and the riding of equids in western Asia. In Prehistoric steppe adaptation and the horse. Marsha Levine, Colin Renfrew, and Katie Boyle, eds. Pp. 115-138. Cambridge: McDonald Institute for Archaeological Research.

O'Connell, Tamsin, Marsha Levine, and Robert Hedges. 2003. The importance of fish in the diet of central Eurasian peoples from the Mesolithic to the early Iron Age. In Prehistoric steppe adaptation and the horse. Marsha Levine, Colin Renfrew and Katie Boyle, eds. Pp. 253-268. Cambridge: McDonald Institute for Archaeological Research.

Okladnikov, Aleksei P. 1959. Ancient population of Siberia and its cultures. Cambridge, MA: Peabody Museum.

Olsen, Sandra L. 2001. The importance of thong-smoothers at Botai, Kazakhstan. In Crafting bone: skeletal technologies through time and space. Alice M. Choyke and László Bartosiewicz, eds. Pp. 197-206. British Archaeological Research International Series 937. Oxford: BAR International. [SLO]

2003. The exploitation of horses at Botai, Kazakhstan. In Prehistoric steppe adaptation and the horse. Marsha Levine, Colin Renfrew, and Katie Boyle, eds. Pp. 83-104. Cambridge: McDonald Institute for Archaeological Research.

- 2006a. Early horse domestication on the Eurasian steppe. In Documenting domestication: new genetic and archaeological paradigms. Melinda A. Zeder, Daniel G. Bradley, Eve Emshwiller, and Bruce D. Smith, eds. Pp. 245-269. Berkeley: University of California Press.

- 2006b. Early horse domestication: weighing the evidence. In Horses and humans: the evolution of human-equine relationships. Sandra L. Olsen, Susan Grant, Alice M. Choyke, and László Bartosiewicz, eds. Pp. 81-113. British Archaeological Research International Series 1560. Oxford: BAR International.

. 2008. The inception of horse pastoralism. General Anthropology 15(1):1, 5-6. [SLO]

Olsen, Sandra L., Bruce Bradley, David Maki, and Alan Outram. 2006. Community organisation among Copper Age sedentary horse pastoralists of Kazakhstan. In Beyond the steppe and the sown: proceedings of the 2002 University of Chicago conference on Eurasian archaeology. David L. Peterson, Laura M. Popova, and Adam T. Smith, eds. Pp. 89-111. Leiden: Brill.

Outram, Alan K., Natalie A. Stear, Robin Bendrey, Sandra Olsen, Alexei Kasparov, Victor Zaibert, Nick Thorpe, and Richard P. Evershed. 2009. The earliest horse harnessing and milking. Science 323(5919):1332-1335.

Outram, Alan K., Natalie A. Stear, Alexei Kasparov, Emma Usmanova, Victor Varfolomeev, and Richard P. Evershed. 2011. Horses for the dead: funerary foodways in Bronze Age Kazakhstan. Antiquity 85(327):116-128.

Panyushkina, Irina P., Barbara J. Mills, Emma R. Usmanova, and Li Cheng. 2008. Calendar age of Lisakovsky Timbers attributed to the Andronovo community of the Bronze Age in Eurasia. Radiocarbon 50(3):459-469. [SLO]

Parzinger, Hermann, and Nikolaus Boroffka, eds. 2003. Das Zinn der Bronzezeit in Mittelasien. I. Die siedlungsarchäologischen Forschungen im Umfeld der Zinnlagerstätten. Archäologie in Iran und Turan, Band 5. Mainz: von Zabern.

Pashkevich, Galena. 2003. Palaeoethnobotanical evidence of agriculture in the steppe and forest-steppe of east Europe in the late Neolithic and Bronze Age. In Prehistoric steppe adaptation and the horse. Marsha Levine, Colin Renfrew, and Katie Boyle, eds. Pp. 287-298. Cambridge: McDonald Institute for Archaeological Research.

Pauketat, Timothy R. 2007. Chiefdoms and other archaeological delusions. Lanham, MD: AltaMira.

Peterson, David L. 2007. Changing technologies and transformation of value in the middle Volga and northeastern Caucasus, circa 30001500 BCE. PhD dissertation, University of Chicago.

. 2009. Production and social complexity: Bronze Age metalworking in the middle Volga. In Social complexity in prehistoric Eurasia: monuments, metals, and mobility. Bryan K. Hanks and Katheryn M. Linduff, eds. Pp. 187-214. Cambridge: Cambridge University Press.

Peterson, David L., Laura M. Popova, and Adam T. Smith, eds. 2006. 
Beyond the steppe and the sown: proceedings of the 2002 University of Chicago conference on Eurasian archaeology. Leiden: Brill.

Pogozheva, A. P., M. P. Rikun, N. F. Stepanova, and S. S. Tur. 2006. Epokha eneolita i bronzy gornogo altaya. Barnaul, Russia: AzBuka.

Polyakov, A. V., and S. V. Svyatko. 2009. Radiouglerodnoe datirovanie arkheologicheskikh pamyatnikov neolita-nachala zheleznogo veka srednego Yeniseya: obzor rezul'tatov i novye dannye. Teoriya $i$ praktika arkheologicheskikh issledovaniy 5:20-55.

Popova, Laura M. 2009. Blurring the boundaries: foragers and pastoralists in the Volga-Urals region. In Social complexity in prehistoric Eurasia: monuments, metals, and mobility. Bryan K. Hanks and Katheryn M. Linduff, eds. Pp. 296-320. Cambridge: Cambridge University Press.

Popova, Laura M., Charles W. Hartley, and Adam T. Smith, eds. 2007. Social orders and social landscapes. Newcastle: Cambridge Scholars.

Possehl, Gregory L. 2002. The Indus civilization: a contemporary perspective. Walnut Creek, CA: AltaMira.

. 2004. The middle Asian interaction sphere: trade and contact in the 3rd millennium BC. Expedition 49(1):40-42.

Postgate, J. N. 1992. Early Mesopotamia: society and economy at the dawn of history. London: Routledge.

Potts, D. T. 1999. The archaeology of Elam: formation and transformation of an ancient Iranian state. New York: Cambridge University Press.

. 2008. An Umm an-Nar-type compartmented soft-stone vessel from Gonur Depe, Turkmenistan. Arabian Archaeology and Epigraphy 19(2):168-181.

Price, T. Douglas, and Gary M. Feinman, eds. 2010. Pathways to power: new perspectives on the emergence of social inequality. New York: Springer. [NNK]

Ranov, V. A., and G. R. Karimova. 2005. Kamennyı̆ vek AfganoTadzhikskǒ̆ depressii. Dushanbe, Tajikistan: Devashtich.

Rassamakin, Yuri. 1999. The Eneolithic of the Black Sea steppe: dynamics of culture and economic development 4500-2300 BC. In Late prehistoric exploitation of the Eurasian steppe. Marsha Levine, Yuri Rassamakin, Aleksandr Kislenko, and Nataliya Tatarintseva, eds. Pp. 59-182. Cambridge: McDonald Institute for Archaeological Research.

2002. Aspects of Pontic steppe development (4550-3000 BC) in the light of the new cultural-chronological model. In Ancient interactions: east and west in Eurasia. Katie Boyle, Colin Renfrew, and Marsha Levine, eds. Pp. 49-74. McDonald Institute Monographs. Cambridge: McDonald Institute for Archaeological Research.

Raulwing, Peter. 2000. Horses, chariots and Indo-Europeans: foundations and methods of chariotry research from the viewpoint of comparative Indo-European linguistics. Archaeolingua Series Minor 13. Budapest: Archaeolingua. [DTP]

Razzokov, Abdurauf. 2008. Sarazm. Dushanbe, Tajikistan: Institut istorii, archeologii i etnografii imeni A. Donnsha, Akademii nauk Respubliki Tadzhikistan.

Roberts, Benjamin W., Christopher P. Thornton, and Vincent C. Piggott. 2009. Development of metallurgy in Eurasia. Antiquity 83(322):1012-1022.

Rogers, J. Daniel. 2007. The contingencies of state formation in eastern inner Asia. Asian Perspectives 46(2):249-274.

Salvatori, Sandro. 2008. Cultural variability in the Bronze Age Oxus civilisation and its relations with the surrounding regions of central Asia and Iran. In The Bronze Age and early Iron Age in the Margiana lowlands. Sandro Salvatori, Maurizio Tosi, and Barbara Cerasetti, eds. Pp. 75-98. British Archaeological Reports 1806. Oxford: Archaeopress.

Salvatori, Sandro, Maurizio Tosi, and Barbara Cerasetti, eds. 2008. The Bronze Age and early Iron Age in the Margiana lowlands. British Archaeological Reports 1806. Oxford: Archaeopress. [CCL-K]
Salzman, Philip C. 2002. Pastoral nomads: some general observations based on research in Iran. Iournal of Anthropological Research 58(2):245-264.

Sarianidi, V. I. 2005. Gonur-Depe: gorod tsarě i bogov. Aşgabat, Turkmenistan: Miras.

Savinov, Dmitrij G. 1997. Okunevskij sbornik: kul'tura, iskusstvo, antropologija. St. Petersburg: Petro-RIF.

Shaffer, Jim G. 1978. Prehistoric Baluchistan, with excavation report on Said Qala Tepe. Delhi: B. R. for Indian Society for Prehistoric and Quaternary Studies.

Shahrani, M. Nazif. 1979. The Kirghiz and Wakhi of Afghanistan: adaptation to closed frontiers. Seattle: University of Washington Press.

Sherratt, Andrew G. 2003. The horse and the wheel: the dialectics of change in the circum-Pontic region and adjacent areas, 45001500 BC. In Prehistoric steppe adaptation and the horse. Marsha Levine, Colin Renfrew, and Katie Boyle, eds. Pp. 233-252. Cambridge: McDonald Institute for Archaeological Research.

Shilov, V. P. 1975. Modeli skotovodcheskikh khoziaistvo stepnikh oblastei Evrazii v epokhu eneolita i rannego bronzovogo veka. Sovetskaya Arkeologiya (1):5-16.

. 1985. Problemy proiskhozhdeniya kochevogo skotovodstva v vostochnoi Evrope. In Drevnosti Kalmykii. K. N. Maksimov, ed. Pp. 23-34. Elista, Russia: Kal'mytskogo NII IFE.

Shishlina, Natalia I. 2001. The seasonal cycle of grassland use in the Caspian Sea steppe during the Bronze Age: a new approach to an old problem. European Journal of Archaeology 4(3):346-366.

- 2004. North-west Caspian Sea steppe; environment and migration crossroads of pastoral culture population during the third millennium BCE. In Impact of the environment on human migration in Eurasia. E. Marian Scott, Andrey Yu. Alekseev, and Ganna Zaitseva, eds. Pp. 91-105. New York: Kluwer.

-2008. Reconstruction of the Bronze Age of the Caspian steppes: life styles and life ways of pastoral nomads. British Archaeological Research Series 1876. Oxford: Archaeopress.

Shnirel'man, Victor A. 1992. The emergence of a food-producing economy in the steppe and forest-steppe zones of eastern Europe. Journal of Indo-European Studies 20(1):123-143.

Sneath, David. 2007. The headless state: aristocratic orders, kinship society, and misrepresentations of nomadic inner Asia. New York: Columbia University Press. [NNK]

Stein, Aurel. 1925. Innermost Asia: its geography as a factor in history. Geographical Journal 65(5):377-403.

Stepanova, N. F. 2009. Problemy absolyutnoy i otnositel'noy khronologii pamyatnikov afanas'evskoy kul'tury Gornogo Altaya. In Rol' estestvenno-nauchnykh metodov $v$ arkheologicheskikhb issledovaniyakh. Iu. F. Kiriushin, A. A. Tishkin, et al., eds. Pp. 154-159. Barnaul, Russia: Izdatel'stvo Altayskogo Gosudarstennogo Universiteta.

Stride, Sebastian, Bernardo Rondelli, and Simone Mantellini. 2009. Canals versus horses: political power in the oasis of Samarkand. World Archaeology 41(1):73-87.

Svyatko, Svetlana V., James P. Mallory, Eileen M. Murphy, Andrey V. Polyakov, Paula J. Reimer, and Rick J. Schulting. 2009. New radiocarbon dates and a review of the chronology of prehistoric populations from the Minusinsk Basin, southern Siberia, Russia. Radiocarbon 51(1):243-273.

Telegin, Dmytri Y. 2002. A discussion on some of the problems arising from the study of Neolithic and Eneolithic cultures in the Azov Black Sea region. In Ancient interactions: east and west in Eurasia. Katie Boyle, Colin Renfrew, and Marsha Levine, eds. Pp. 26-48. Cambridge: McDonald Institute for Archaeological Research.

Teufer, Mike. 1999. Ein Scheibenknebel aus Džarkutan (Süduzbekistan). Archäologische Mitteilungen aus Iran und Turan 31:69-142. [DTP]

Thornton, Christopher P. 2009. The emergence of complex metal- 
lurgy on the Iranian Plateau: escaping the Levantine paradigm. Journal of World Prehistory 22(3):301-327.

Tosi, Maurizio. 1972. Iran, l'alba della civiltà. Milan: Provinciali Spotorno.

Tosi, Maurizio, and Marcello Piperno. 1973. Lithic technology behind the ancient lapis lazuli trade. Expedition 16(1):15-23.

Tsybiktarov, Aleksandr D. 1998. Kul'tura plitochnykh mogil Mongolii i Zabaikal'ia. Ulan-Ude, Russia: Buryat University Press. [NNK]

Vadetskaya, E. B. 1986. Arkeologicheskie Pamyatniki v stepyakh srednevo Yeniseya. Leningrad: Akademiya Nauk CCCP.

Vainshtein, S. I. 1991. Mir kochevnikov tsentral'nyi Azii. Moscow: Nauk.

Vambery, Arminius. 1873. History of Bokhara. Oxford: King. [CCL$\mathrm{K}]$

Vinogradova, N. 1993. Interrelation between farming and "steppe" tribes in the Bronze Age, south Tadjikistan. In South Asian archaeology 1991: proceedings of the Eleventh International Conference of the Association of South Asian Archaeologists in Western Europe. Adalbert J. Gail and Gerd J. R. Mevissen, eds. Pp. 289-301. Stuttgart: Steiner.

Vinogradova, N. M., V. A. Ranov, and T. Filimonova. 2008. Pamyatniki
Kangurttuta $v$ Yugo-Zapadnom Tadzhikistane (épokha neolita i bronzovy̌ vek). Moscow: IV RAN.

Wells, R. Spencer, Nadira Yuldasheva, Ruslan Ruzibakiev, Peter A. Underhill, Irina Evseeva, Jason Blue-Smith, Li Jin, et al. 2001. The Eurasian heartland: a continental perspective on Y-chromosome diversity. Proceedings of the National Academy of Sciences of the USA 98(18):10244-10249.

Wright, Joshua, William Honeychurch, and Chunag Amartuvshin. 2009. The Xiongnu settlements of Egiin Gol, Mongolia. Antiquity 83(320):372-387.

Younghusband, George J. 1908. The story of the guides. Boston: Macmillan. [CCL-K]

Zaĭbert, V. F. 1993. Éneolit uralo-irtyshskogo mezhdurech'iya. Petropavlovsk, Russia: Nauka.

Zarins, Juris. 1990. Early pastoral nomadism and the settlement of lower Mesopotamia. Bulletin of the American Schools of Oriental Research 280:31-65.

Zeder, Melinda, Eve Emshwiller, Bruce D. Smith, and Daniel G. Bradley. 2006. Documenting domestication: the intersection of genetics and archaeology. Trends in Genetics 22(3):139-155. 